\title{
Castor oil (Ricinus communis): a review on the chemical composition and physicochemical properties
}

\author{
Akwasi YEBOAH ${ }^{1}$, Sheng $\mathrm{YING}^{2}$, Jiannong $\mathrm{LU}^{1}$, Yu XIE ${ }^{1}$, Hanna AMOANIMAA-DEDE ${ }^{1}$, \\ Kwadwo Gyapong Agyenim BOATENG ${ }^{3}$, Miao $\mathrm{CHEN}^{1 \star}$, Xuegui YIN ${ }^{1 \star}$ (D)
}

\begin{abstract}
Increasing world population has markedly increased the demand for vegetable oils for domestic and industrial purposes. Plant-based vegetable oils have been identified as one of the oils with high nutritive value. Castor plant is one of the oilseed with rich oil content owing to its high monounsaturated fatty acid and bioactive compounds. Its fatty acid profile constitutes mainly of ricinoleic acid and other minor acids such as stearic, palmitic, and oleic acid. Ricinoleic acid of castor oil is unique among all other vegetable oils, making it attractive for a wide spectrum of applications. The predominant triglyceride component in the oil is triricinolein. Minor biological compounds including carotenoid, tocopherol, tocotrienol, phytosterol, phospholipid, phytochemical, and phenolic compounds are present in castor oil. These compounds offer oxidation stability, anti-inflammatory, and antioxidant properties to the oil. The acid, anisidine, iodine, viscosity, and saponification values indicate that castor has good oil quality compared to other vegetable oils. Castor oil composition is influenced by the area of production and method of extraction adopted. The chemical structure of castor oil is centered on the ricinoleic acid and three major functional groups linked by glycerol moiety. More research on the oil's component is being investigated nevertheless efficient and eco-friendly extraction methods are required. This review, therefore, summarizes the castor oil composition namely the triglyceride, various fatty acids and bioactive compounds, extraction methods, as well as its physicochemical properties.
\end{abstract}

Keywords: castor oilseed; fatty acids; phytosterols; ricinoleic acid; tocopherols.

Practical Application: Suitability of castor oil for domestic and industrial purposes.

\section{Introduction}

Ricinus communis is an annual oilseed crop commonly known as castor. It is sometimes called castor bean, but it's not a true bean in nature. Castor plant, belonging to the spurge family Euphorbiaceae can grow in different geographical areas (Anjani, 2014). Growth of castor is favorable around $20^{\circ} \mathrm{C}$ to $25^{\circ} \mathrm{C}$ whereas temperatures lower than $12{ }^{\circ} \mathrm{C}$ or higher than $38^{\circ} \mathrm{C}$ affects germination and yield (Severino et al., 2012; Yin et al., 2019). The plant growth and appearance vary greatly including its growth pattern, seed color and size, stem color and foliage, as well as oil content Figure 1 (Ramanjaneyulu et al., 2013; Sbihi et al., 2018). Castor seed is characterized by its elongated, ovoid, oval, or square shape; size variable, 0.5 to $1.5 \mathrm{~cm}$ long. Its seed color comprises a base color that varies from brown or red to black, brownish yellow, grey, and white Figure 1. The pattern as such ranges from fine to coarse vein-like or finely dotted to broad splotches (Naik, 2018; Salihu et al., 2014). The leaves change from pale green to dark red based on the content of anthocyanin pigmentation (Sbihi et al., 2018). The shape of the fruit is globe-like resembling a spiny capsule. The capsule which encloses the seeds cracks when fully matured Figure 1.
Castor oil extracted from the seed mostly using $n$-hexane is very versatile Figure 1. Thus, it is utilized in several sectors such as agricultural, pharmaceutical, and industrial sectors. Products of castor oil include; ointments, nylon, varnishes, airplane engine lubricants, hydraulic fluids, dyes, detergents, plastics, synthetic leather, cosmetics, and perfumes (Anjani, 2014; Severino et al., 2012; Ying et al., 2017). Currently, castor oil production is predominant in India, China, and Brazil (Gad-Elkareem et al., 2019; Perdomo et al., 2013). The percentage of seed oil content ranges from 40 to $60 \%$ and the annual oil production is about 1.8 million tons worldwide (Perdomo et al., 2013). The chemistry of castor oil is based on the ricinoleic acid structure, carboxylic group, hydroxyl group, and the single point of unsaturation (Mubofu, 2016; Yusuf et al., 2015). These features provide additional strength to the oil structure. The fatty acid profiles present in castor oil are ricinoleic, oleic, stearic, palmitic, linoleic, linolenic acid and among others. Among them, ricinoleic acid, a monounsaturated fatty acid is the dominant acid constituting about 75 to $90 \%$ of the total oil composition (Beruk et al., 2018; Panhwar et al., 2016; Yusuf et al., 2015). It is worth saying that, the castor oil is the sole oil with such a high amount of fatty acid and this makes it unique from other vegetable oils. The fatty acid profile of castor 

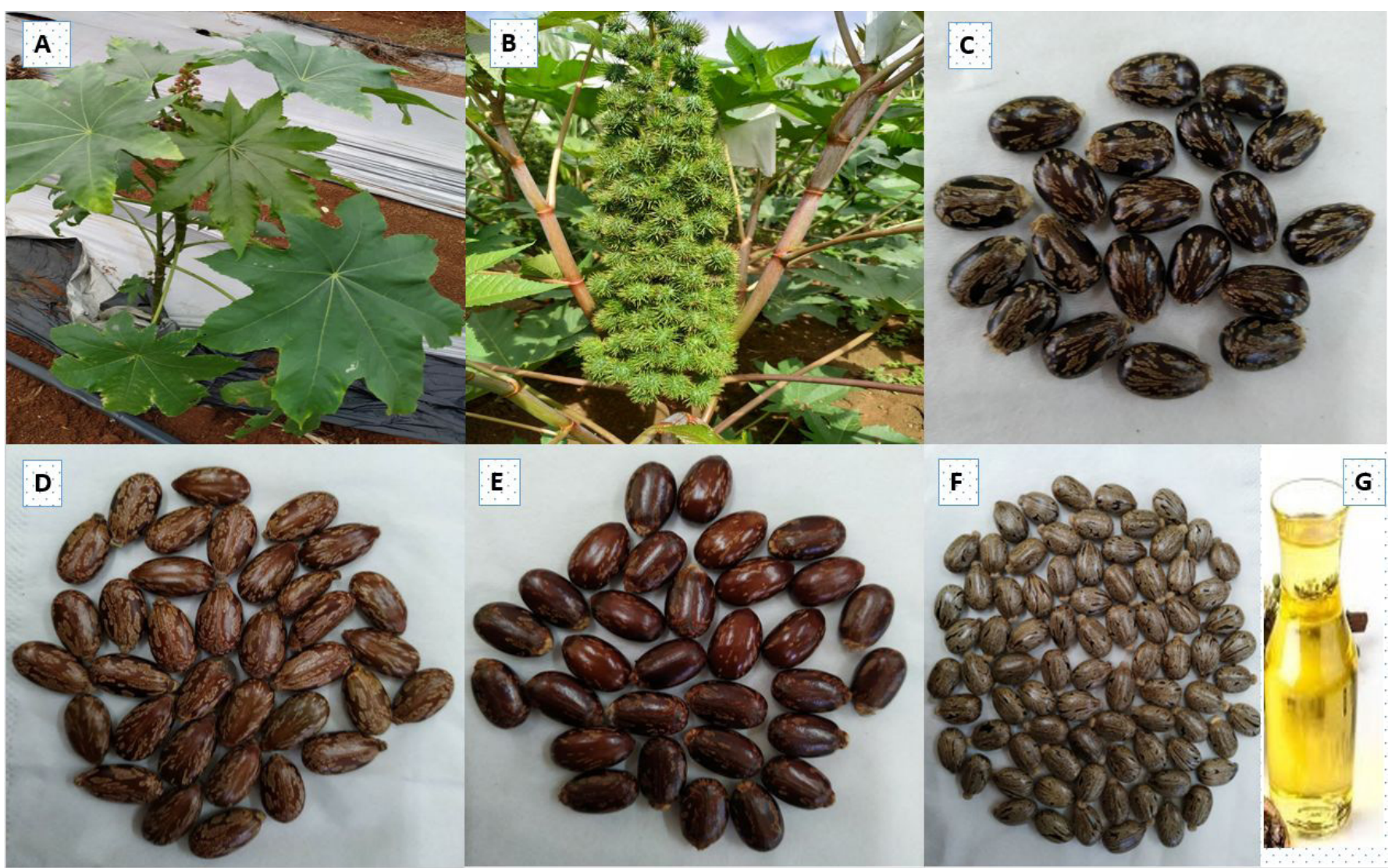

Figure 1. Castor; (A) young castor plant; (B) matured castor capsules; (C-F), different colors and varieties of castor seeds; (G) castor oil.

has low amount of saturated and polyunsaturated fatty acids and this enhance its stability (Yusuf et al., 2015). Like other vegetable oils, the composition and properties of castor oil vary with respect to the method of extraction, geographical location, and type of cultivar. The fatty acid profile of castor oil shares a higher similarity with that of macadamia nut, palm kernel, olive, and sunflower oil (Nor Hayati et al., 2009; Sinanoglou et al., 2014).

Over the past decades, an increase in world population has dramatically increased the demand for vegetable oils for domestic and industrial purposes. Recent research has unveiled that nutritional unsaturated acids play an important role in reducing individual risks associated with diseases such as asthma, cardiovascular diseases, cancer, and diabetes (Ganesan et al., 2018). Plant-based vegetable oils have been identified to possess high amount of unsaturated fatty acid and certain biological antioxidants that are effective against several disease (Abdallah et al., 2015; Ganesan et al., 2018). Castor plant is one of the non-oilseed with high nutritional value owing to its rich amount of monounsaturated fatty acid (90\%) and bioactive active compounds such as vitamin $\mathrm{E}$ component (tocopherols or tocotrienols), phospholipids, phenolics among others (Said et al., 2016; Sbihi et al., 2018). These compounds also account for castor oils stability and flavor making it suitable for many purposes (Sedeek et al., 2012). Tocopherols are one of the natural antioxidants present in castor oil with anti-proliferative and anti-inflammatory properties. The primary tocopherol isomers, $43.1-96.62 \mathrm{mg} / \mathrm{g}$ for $\delta$ and $30.89-52.7 \mathrm{mg} / \mathrm{g}$ for $\gamma$ are relatively higher than those reported in olive, hazelnut, and sunflower (Said et al., 2016; Sbihi et al., 2018). Also, its physicochemical properties such as low acid and iodine value, high saponification value, and thiobarbituric acid indicate that castor oil has good oil quality. The acid and iodine value of the oil reflects its quality at $1.34 \mathrm{mg} \mathrm{KOH} / \mathrm{g}$ oil and $83 \mathrm{gI}_{2} / 100 \mathrm{~g}$, respectively (Omari et al., 2015). Several studies have been conducted on the fatty acid composition, however, information about the biologically active compounds present in castor oil is very limited.

In this present review, the structure of castor oil, extraction methods, fatty acid profile, and neutral lipids (triglyceride) found in castor oil have been highlighted. The various biologically active compounds and physicochemical properties have also been discussed. This review also compares the physicochemical properties and composition of castor oil with other vegetable oils.

\subsection{Extraction and uses of castor oilseed}

In many parts of the world, castor oils are mostly purchased in the form of cold-pressed oils. Research has revealed that castor oil can be extracted by pressing, solvent extraction technique mostly utilizing $n$-hexane, and super-critical carbon dioxide $\left(\mathrm{SC}_{-} \mathrm{CO}_{2}\right)$ (Danlami et al., 2015a, b; Guo et al., 2018). Before extraction, castor seeds are first cleaned to remove any unwanted material. The seed is then put into decorticating machines to dehull the shells leaving the kernels. The more efficient the decorticating 
process the lighter the oil color. Mostly, more than $90 \%$ of castor oil is obtained by using solvent extraction technique. However, the high price value and sustainability of biodiesel-based solvents are the major concern with the use of this technique (Patel et al., 2016). As a result, different solvents involving ethanol and $\mathrm{SC}-\mathrm{CO}_{2}$ have been studied and adopted for castor oil extraction. The use of aqueous solvents has demonstrated to be as efficient as hexane with the additional benefit of low solvent requirement. Nevertheless, one setback with aqueous solvents is the high energy production needed to separate the liquid from the oil (Mutlu \& Meier, 2010; Patel et al., 2016). SC-CO is preferred to organic solvents (ethylene monoethyl ether, diethyl ketone, methyl acetate) because it is cost-effective, non-explosive, and non-toxic (Danlami et al., 2015a; Maleki et al., 2013).

With extraction of castor oil using $n$-hexane, the oil content vary from 34.6 to 56.6\% (Panhwar et al., 2016; Sbihi et al., 2018; Severino et al., 2015). This variation may be attributed to changes in climatic conditions, geographical location, and type of variety (Severino et al., 2015). With SC- $\mathrm{CO}_{2}$ as an extraction medium, only a few studies have analyzed the oil content in castor with this technique. The reported optimal yield with $\mathrm{SC}-\mathrm{CO}_{2}$ in castor is $9.29 \%$ (Danlami et al., 2015a). This value is very low compared to that obtained by hexane (56.6\%). Particle size of the ground seed is one paramount factor that influences oil yield during extraction (Beveridge et al., 2005). It has been found that particle size of $0.35 \mathrm{~mm}$ or lesser is desirable for maximum oil yield (Beveridge et al., 2005). Danlami et al. (2015a) reported about $1 \mathrm{~mm}$ particle sizes of the castor seeds which may be due to the low oil yield. Moreso, operational conditions such as temperature, time range, and moisture content vary and influence oil yield in oilseed (Danlami et al., 2015a). Therefore, studies involving these conditions may be further investigated to improve castor oilseed yield by using $\mathrm{SC}-\mathrm{CO}_{2}$. Overall, further studies are required on castor oilseed extraction as well as the effects on the oil quality.

Castor oil is a vital raw material and has been used to produce more new bio-based chemicals and materials than any other plant produced oils (Anjani, 2014). In the past, the use of castor oil was limited mainly to manufacturing lamp oils, industrial lubricants, and medicine (Anjani, 2014). However, a better understanding of the chemical structure has broadened it's use and resulted in the production of more byproducts that are beneficial to humans. In medicine and other health-related fields, castor oil has been widely used to treat several kinds of diseases owing to its anti-inflammatory property. Castor products have been applied to treat minor issues like menstrual pain, gastrointestinal infection, athlete's foot, sunburns, and induction of labor pain (Anjani, 2012; Kelly et al., 2013). It contains purgative or laxative and thus can be good for constipation treatment. In Nigeria, detoxified castor seed is used as a food condiment (Salihu et al., 2014), a substance that benefits human vision.

Limited information is available on the use of castor oilseed in the food industry. The oil is used as a mold inhibitor in food preservation and manufacturing of additives, flavors, and candy (Wilson et al., 1998). Polyoxyl (e.g., Kolliphor EL) castor oil is used as an emulsifier and non-ionic solubilizer produced by mixing ethylene oxide with castor oil (Patel et al., 2016). The oil is greatly utilized in countries like Nepal, Pakistan, and India, where it is poured on top of foodstuffs (wheat, pigeon pea) during storage to prevent spoilage (Wilson et al., 1998).

The seed cake of castor contains toxic compounds such as ricin. This compound can affect human health and even animals when consumed (Severino et al., 2012). However, several methods have been identified to be effective in detoxifying this toxic component, thereby making it useful for other purposes. Castor meal detoxified by autoclaving can be used to substitute about $67 \%$ of soybean meal for sheep (Borja et al., 2017). Also, through fermentation or boiling, castor meal is detoxified and this can be used as a supplement in broiler-finisher (Akande et al., 2016). Castor residue called pomace with high amount of nitrogen is used as animal feed and as organic fertilizer without any reported harmful effects (Borja et al., 2017).

\subsection{Structure of castor oil}

The structure of castor oil is made up of triglycerides that lack glycerin. The triglyceride molecule has a long 18-carbon chain with a double bond (Patel et al., 2016). Its chemistry is based mainly on the ricinoleic acid structure, carboxyl group, hydroxyl group, and a single point of unsaturation Figure 2 (Mubofu, 2016; Ogunniyi, 2006). The carboxylic group in castor oil molecule allows production of a wide range of esterification products. The hydroxyl $(-\mathrm{OH})$ group on the $12^{\text {th }}$ carbon can be acetylated or eliminated through a dehydration process to upsurge the unsaturation to give a semi-drying oil (Nezihe et al., 2010; Sinadinović-Fišer et al., 2012). Through caustic fusion and high-temperature pyrolysis, the reactive site of the hydroxyl group can be splited to generate useful products with shorter chains (Patel et al., 2016). In addition, the hydroxyl group provides more strength to the structure to prevent the formation of hydroperoxides (Razdi, 2012). The double bond in the structure can be modified through the process of carboxylation, epoxidation or hydrogenation (Alwaseem et al., 2014). Lastly, the single point of unsaturation can be altered through the process of epoxidation and hydrogenation. Hydrogenated castor oil, which is a wax-like substance, can be obtained from the oil via hydrogen reduction (Patel et al., 2016).

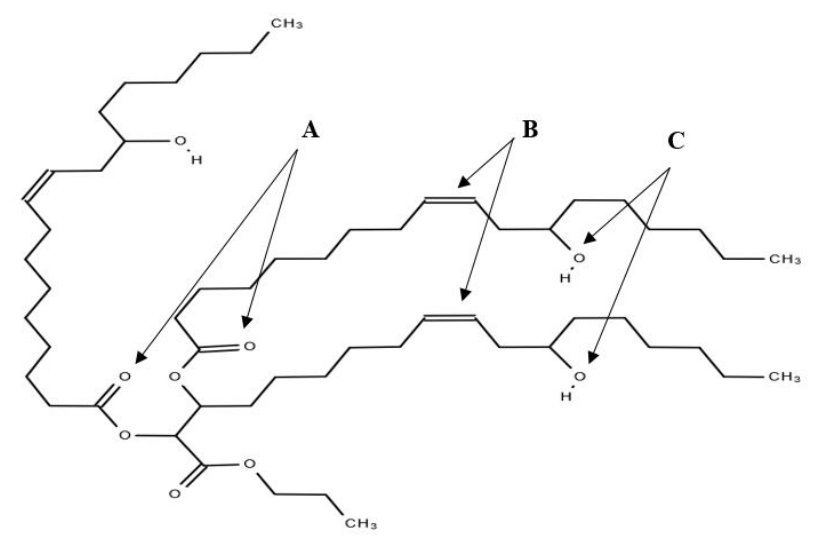

Figure 2. Structure of castor oil molecule. (A) indicates carboxylic groups; (B) indicates double bonds; (C) indicates hydroxyl groups. 


\subsection{Composition of castor oilseed}

The composition of castor oil is mainly composed of fatty acids and neutral lipids (triglycerides). Other minor biological active compounds that consist of unsaponifiable fractions such as carotenoids, phenolics, phospholipids, phytochemicals, phytosterols, tocopherols, and tocotrienols are also present in the oil. In the following subsections, these components and their nutritional benefits in castor oilseed explored by different researchers have been discussed.

\section{Triglycerides (TAG)}

Majority of the triacylglyceride (TAG) molecules found in castor oil contain three molecules of ricinoleic acid linked to a glycerol moiety (Mubofu, 2016; Ogunniyi, 2006; Patel et al., 2016). Ndiaye et al. (2005) reported the compositions of triglycerides in castor oil Figure 3. A later study by Salimon and others found only five triacylglycerides in castor oil and their contents: diricino-leoylpalmitoyl-glycerol (RRP) (0.9\%), diricino-leoyllinoleoylglycerol (RRL) (1.2\%), diricino-leoyloleoyl-glycerol (RRO) (5.6\%), diricino-leoystearoyl-glycerol (RRS) (8.2\%), and triricinolein (RRR) (84.1\%) (Salimon et al., 2010). Also, in two different studies the contents of RRR (the most predominant TAG) were found to be at $70 \%$ and 63\%, respectively (Lin, 2009; Plante et al., 2011). Several factors such as the area of production, cultivar, oil extraction process, harvesting period, and storage time affect triacylceride composition of vegetable oils (Lin, 2009; Lin \& Chen, 2012). Hence, the relative percentage of triacylceride composition in castor may be attributed to these factors. In addition, some tetraacylglycerols in castor oil are (12-ricinoleoyl - ricinoleoyl) -ricinoleoyl - linolenoyl-glycerol (RRRLn), (12-ricinoleoyl ricinoleoyl) - ricinoleoyl-stearoyl-glycerol (RRRS), (12-ricinoleoyl - ricinoleoyl)- ricinoleoyl-oleoyl-glycerol (RRRO), (12-ricinoleoyl

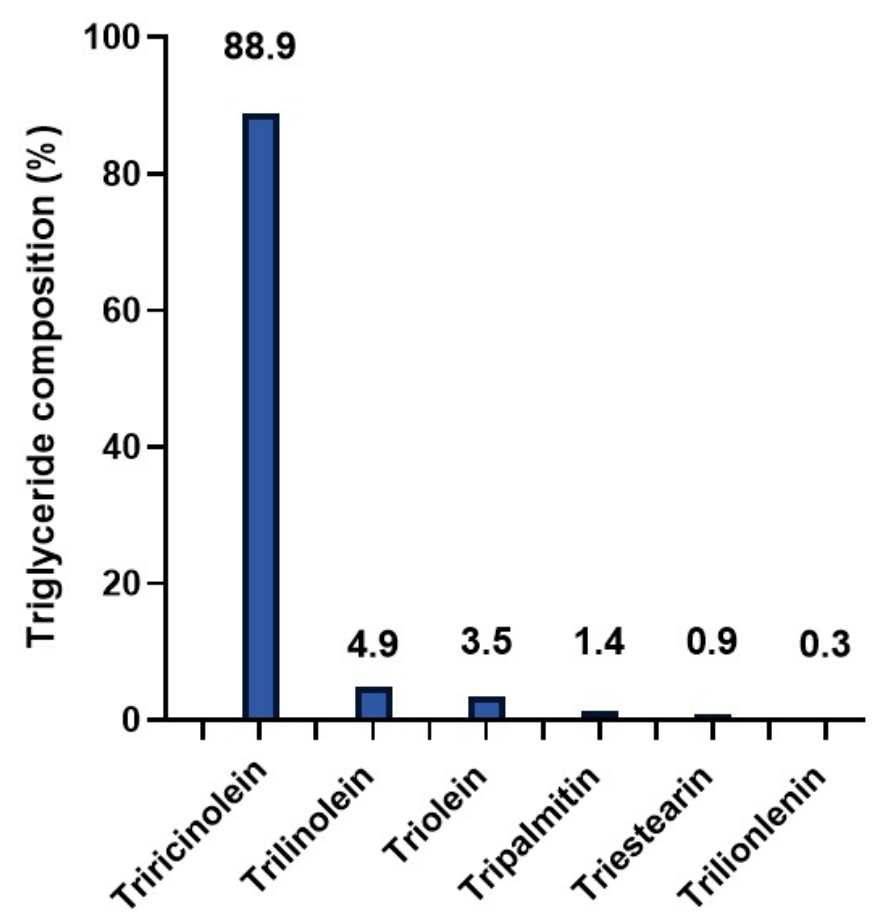

Figure 3. Triglyceride composition of castor oil (Ndiaye et al., 2005).
- ricinoleoyl) -ricinoleoyl-palmitoyl-glycerol (RRRP), and (12-ricinoleoyl - ricinoleoyl) - ricinoleoyl-linoleoyl-glycerol (RRRL). These acylglycerols were determined by HPLC, and only $3 \%$ of the castor oil of the overall acylglycerols contained polyhydroxy fatty acids, whereas the individual acylglycerols were $0.5 \%$ (Lin \& Chen, 2012).

\section{Fatty acids}

The discovery of fatty acids has been long known in plants. Saalmülle first reported castor oilseed fatty acid composition in 1848 and named an isolated hydroxyl acid as ricinoleic acid (Saalmüller, 1848). Ricinoleic acid (C18:1-OH), a monounsaturated fatty acid, is the major component present in castor oil (Omohu \& Omale, 2017). It has 18-carbon chain and one double bond at the $12^{\text {th }}$ carbon with the molecular formula $\mathrm{C}_{18} \mathrm{H}_{34} \mathrm{O}_{3}$ Table 1 (Román-Figueroa et al., 2016). Latter, studies showed that castor oilseed contains several fatty acids, including linoleic acid (C18:2), linolenic acid (C18:3), oleic acid (C18:1), palmitic acid (C16:1), stearic acid (C18:0) among others Table 1 (Omari et al., 2015; Omohu \& Omale, 2017). The presence of linolenic acid and oleic acid in vegetable oils are highly beneficial to human health and have been used to treat several human sicknesses such as diabetes, skin cancer, renal disease, heart attack, lupus, high blood pressure and high cholesterol level (Ganesan et al., 2018). Oleic acid is resistant to oxidation and can be used to improve the functions of antioxidants and as anti-polymerization agents (Anjani, 2012). When combined with antioxidants (e.g., tocopherols) it can be blended with other oils to prevent oxidation. Linoleic, palmitic, stearic acids contain some useful properties good for the skin, thus used in many cosmetic industries (Ganesan et al., 2018). Esters of stearic acid: glycol distearate, glycol stearate, and ethylene glycol are used to manufacture cosmetic products or to increase the pearly effect of shampoos (Gunstone \& Hamilton, 2004). The occurrence of these fatty acids in castor oil propose the nutritional and industrial benefit of this plant.

As with other oilseed crops, the type of cultivars, the geographical origin of the crop, or the time of harvest influence the relative proportion of the fatty acids composition (Yusuf et al., 2015). Table 2 shows that the percentage of ricinoleic acid in castor oilseed from India, China, Brazil, Ethiopia, Pakistan, Saudi Arabia, Nigeria, and Tanzania were 87.3, 90.85, 88.2, 91.06, $94.59,75.77,86.96$, and $87.8 \%$, respectively. The ricinoleic acid in castor oil from Pakistan was the highest with $94.59 \%$ whereas Saudi Arabia was the least with 75.77\% (Panhwar et al., 2016; Sbihi et al., 2018). Researchers have shown that ricinoleic acid is present in the endosperm and cotyledon of immature castor seed but not in developed male flowers (Brown et al., 2012). Its oil formation is speculated to form a positive correlation with oleic acid (Möllers \& Schierholt, 2002), and an increase of ricinoleate content increases seed weight and size (Huang et al., 2015). Therefore, it can be said that selective breeding for high ricinoleic oil content can lead to an increase in seed weight, size, and oleic acid content in castor.

The variation in fatty acids component in Table 2 shows a clear variation according to location such that certain fatty acids present in some locations are absent in other locations. 
Table 1. Chemical structures of different fatty acids in castor oil.

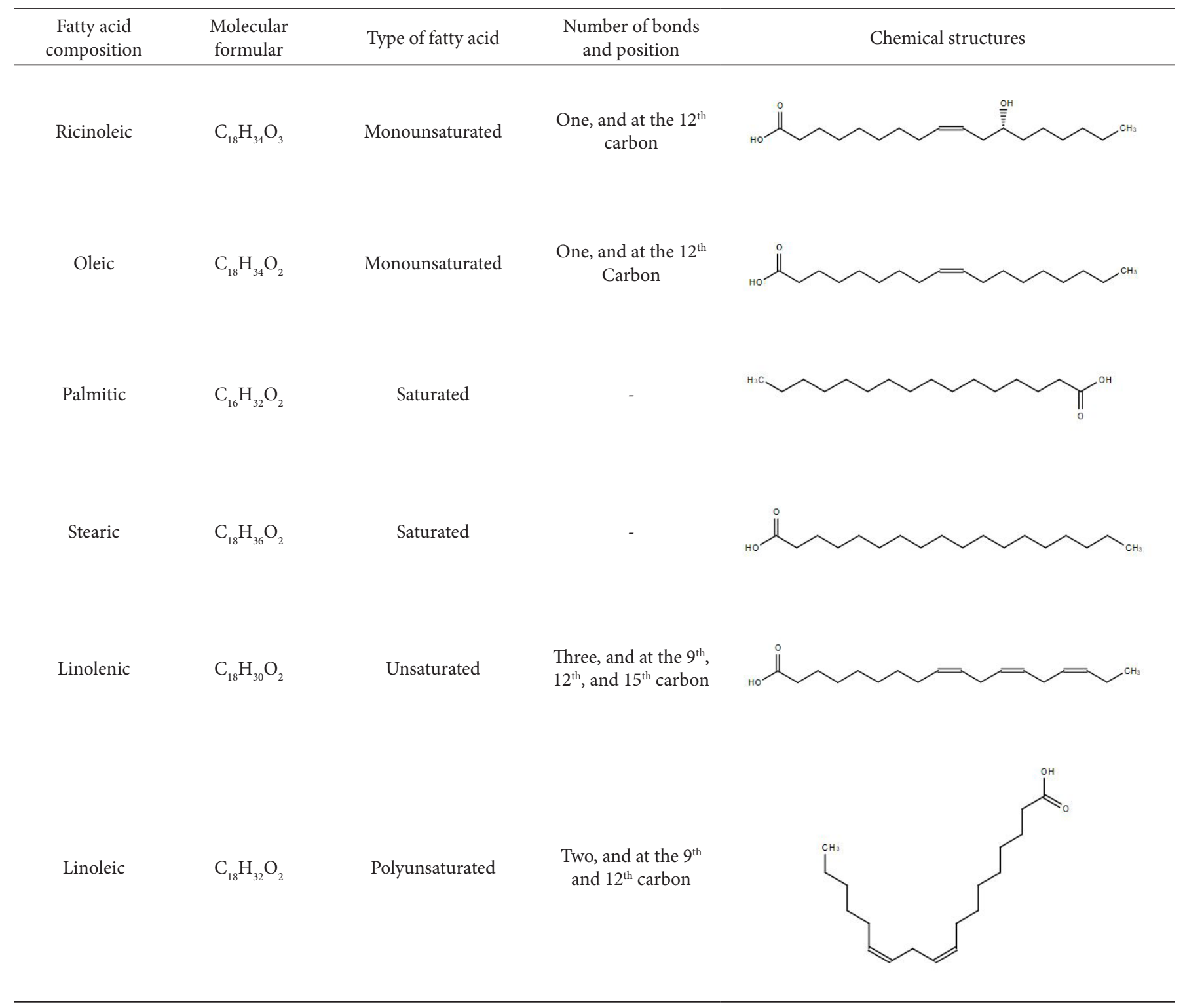

Table 2. \% compositions of fatty acids in castor oil from various regions.

\begin{tabular}{lcccccccc}
\hline \multicolumn{1}{c}{ Fatty acid } & India (a) & China (b) & Brazil (c) & Ethiopia (d) & Pakistan (e) & Saudi Arabia (f) & Nigeria (g) & Tanzania (h) \\
\hline Ricinoleic (C18:1-OH) & 87.3 & 90.85 & 88.2 & 91.06 & 94.59 & 75.77 & 86.96 & 87.8 \\
Oleic (C18:1) & 4.69 & 2.82 & 3.8 & 2.93 & 2.05 & 7.40 & 5.10 & 4.1 \\
Linoleic (C18:2) & 4.92 & 3.74 & 4.9 & 3.48 & 1.84 & 8.94 & nd & 4.3 \\
Stearic (C18:0) & 1.241 & 0.64 & 0.9 & 0.91 & 0.45 & 3.05 & $\mathrm{nd}$ & 1.4 \\
Palmitic (C16:1) & 1.016 & 0.72 & 1.4 & 1.08 & 0.31 & 2.77 & 0.56 & 2.4 \\
Linolenic (C18:3) & 0.63 & - & 0.3 & 0.316 & $\mathrm{nd}$ & $\mathrm{nd}$ & $\mathrm{nd}$ \\
\hline
\end{tabular}

(a) (Ramanjaneyulu et al., 2013) (b) (Guo et al., 2018) c) (Souza Schneider et al., 2004) (d) (Beruk et al., 2018) (e) (Panhwar et al., 2016) (f) (Sbihi et al., 2018) (g) (Omohu \& Omale, 2017) (h) (Omari et al., 2015). Key; nr-not reported, nd-not detected.

For example, linoleic and linolenic acid are present in castor oilseed from some countries but were absent in Nigerian and Saudia Arabian samples (Omohu \& Omale, 2017; Sbihi et al., 2018). This may be related to the type of cultivar and climatic or environmental factors. Moreover, the methods of analysis adopted differ among the authors which could also be a contributing factor. For instance, Souza Schneider et al. (2004) used gas chromatography-mass spectrometry (GC-MS) for fatty acids analysis whereas Omohu \& Omale (2017) employed gas chromatography (GC). GC-MS is more advantageous with 
accurate results in that, it reveals certain compounds using both mass spectrum and retention time compared to GC. The overall content of saturated fatty acid in samples from Nigeria is low with $5.66 \%$ in castor and a maximum of $11.3 \%$ from Brazil (Souza Schneider et al., 2004; Omohu \& Omale, 2017).

\section{Phytosterols}

Phytosterols are one of the minor bioactive compounds that consist of unsaponifiable fraction in castor oilseed (Sbihi et al., 2018). The dominant phytosterol class up to 93.8\% in castor was found to be 4-desmethylsterols and $\beta$-sitosterol was the abundant compound present with 47.1\% (Said et al., 2016). Campesterol, stigmasterol, and $\Delta-5$ avenasterol were the other 4-desmethylsterols identified. A total phytosterol compound of $98.1 \mathrm{mg} / 100 \mathrm{~g}$ oil was also found in castor oil (Velasco et al., 2015). Sbihi et al. (2018) examined castor sterols and concluded that $\beta$-sitosterol is the main sterol component among detected sterols. The percentage of cholesterol was as low as $0.09 \%$, but (Lechner et al., 1999; Velasco et al., 2015) in their studies detected no cholesterol in their samples which could be due to varietal differences. Phytosterol content is influenced by the area of planting, cultivar, and temperature where an increase in temperature resulted in higher levels (Aparicio et al., 2013). Although the oilseed of castor is mostly utilized for industrial purposes, phytosterols could be extracted from the raw oil refining waste products. In this scenario, the production of castor cultivars with high phytosterol component may contribute to the valuable co-products of the chain length. Phytosterols are important in human diet owing to their decreasing serum low-density lipoprotein cholesterol levels (Velasco et al., 2015). They are greatly recommended as elements for a broad range of fortified foods and, therefore a better understanding of the individual phytosterols content in castor oil may contribute to its potential use in the food industry.

\section{Phospholipids}

One class of lipids that form lipid bilayers in the cell membrane are phospholipids. A combination of phospholipids and tocopherols may delay the onset of lipid oxidation (Chew \& Nyam, 2019). Information about phospholipids is useful in pharmaceutical and food industries, particularly as emulsifier.

The phospholipid composition of castor oilseed has long been studied. Moreau et al. (1980) reported in castor that the total polar lipids was less than $1 \%$, with phosphatidylcholine, phosphatidylinositol, and phosphatidylethanolamine as the major components. Among them, phosphatidylcholine was the most predominant at $30 \%$. Donaldson also reported $2 \%$ of phospholipid of 2-day-old castor oilseed and the values of phospholipid classes were similar (Donaldson, 1976). Comparing to other oilseed crops such as chufa nuts with 5.4\%, the phospholipid values reported in castor are low (Oderinde \& Tairu, 1992). Normally, dark-colored oils are a result of high proportions of phospholipid. Hence the clear pale yellow color of castor oil may be due to the low amount of phospholipid content in the oils.

\section{Tocopherols and tocotrienols}

Lipid-soluble antioxidants such as tocopherols in oilseed scavenge free-radicals. Isomers of tocopherols (in vitro and in vivo) have different antioxidant activity. In vitro antioxidant activity of tocopherols prevents unsaturated fatty acids from oxidation whereas in vivo tocopherols also known as Vitamin E homologues inhibit inflammatory damage, proliferative, and cellular tissues from oxidation (Baümler et al., 2017). The four naturally tocopherols $(\alpha-, \beta-, \gamma-$, and $\delta$-tocopherol) which vary in their antioxidant properties and chemical structure have been identified in many oilseeds including castor (Ribeiro et al., 2014).

Velasco et al. (2015) investigated the variability of castor seed quality traits and found all the tocopherol isomers in the oil. $\delta$ - and $\gamma$-tocopherol were also the main isomers present in the oil (Said et al., 2016; Velasco et al., 2005). $\alpha$-tocopherols are noted for their vitamin $\mathrm{E}$ homologues and $\delta$ - as well as $\gamma$-tocopherol are highly effective as in vitro antioxidants (Ribeiro et al., 2014). The long oil's shelf life, anti-inflammatory property, and oxidative stability of castor oil at high temperature may be associated to the presence of these tocopherols in the oils. Moreover, tocopherols control the membrane functions by inhibiting oxidation of body lipids, organelle membranes, and reduce individual risks associated with contracting diseases such as Alzheimer's, cancer, and heart disease (Ramadan, 2019). Therefore the presence of tocopherols suggests that castor oilseed may be beneficial against these diseases.

Besides tocopherols, tocotrienols are also naturally antioxidants in oils, belonging to the Vitamin E group, with $\alpha$ - and $\beta$ - analogs. Tocotrienols provide neuroprotective properties and prevent cholesterols biosynthesis (Ramadan, 2019). Tocotrienols are identified in their unsaturated form. The limited studies available on the tocotrienols content of castor oil have revealed that $\alpha$ - and $\beta$-tocotrienols are the main tocotrienols found in the oilseed (Said et al., 2016; Sbihi et al., 2018).

\section{Phenolic compounds}

Phenolic compounds involve various groups of secondary metabolites. This compound has either one or more hydroxyl groups that bind directly to aromatic compounds (Rampadarath et al., 2014). The major classes of nutritional phenolic compounds include flavonoids, phenolic acids, and tannins. Hydroxycinnamic acid and hydroxybenzoic acid are the two main subgroups of phenolic acids (Chew \& Nyam, 2019). Hydroxybenzoic acids mostly have the aromatic ring with $\mathrm{C} 1-\mathrm{C} 6$ structure and their by-product are gallic, syringic, and vanillic acids (Boualem et al., 2017). With hydroxycinnamic acids, their derivatives include caffeic, ferulic, and $p$-coumaric acids with C3-C6 structure (Ramadan, 2019). The type and content of phenolic compounds differ among different oils. Phenolic compounds contribute to the flavor and antioxidant activity in oils.

Chakravartula \& Guttarla (2007) used methanol-ether to extract phenolic acids from defatted castor oilseed. The concentration of the total Gallic Acid Equivalent (GAE) was unknown. HPLC-SPD chromatogram analysis detected five acids namely ferulic, syringic, $p$-coumaric, $o$-coumaric, and cinnamic. The separation of different phenolic acids in 
castor depends on their polarities and structural similarities (Chakravartula \& Guttarla, 2007). The separation of ferulic and $p$-coumaric acid was easily resolved compared to ferulic acid and syringic, $o$-coumaric, $p$-coumaric, and cinnamic acids (Chakravartula \& Guttarla, 2007). Other phenolic acids such as chlorogenic, gallic, gentistic, and protocatechuic have also been identified in castor oilseed (Boualem et al., 2017). The extraction of phenolic compounds in castor oil varies among the method of extraction and the part of tissue analyzed. Recently, the total phenolic content of castor root extracts by ethanol gave the highest with $135.06 \mathrm{mg} \mathrm{GAE} / \mathrm{g}$ than $50.24 \mathrm{mg} \mathrm{GAE} / \mathrm{g}$ for ethyl acetate extracts and $25.50 \mathrm{mg}$ GAE/g as the least by hexane extract (Santos et al., 2018). Through hydrogen bonds, phenolic compounds of hydroxyl moieties form stronger intermolecular linkage with polar solvents (Rampadarath et al., 2014). Hexane is a non-polar extraction solvent whiles ethanol is polar solvent therefore the highest GAE extract by ethanol can be associated with its polarity which forms hydrogen bonds during phenolic compound extract.

\section{Phytochemicals}

The evaluation of antimicrobial and phytochemical activity in castor oil revealed that flavonoid, cyanogenic glycoside, saponin, oxalate, phytate, alkaloid, and tannin were present in the ascending order (Momoh et al., 2012). Udegbunam et al. (2015) in their studies also detected these biologically active chemical compounds in castor oilseed during screening of in vitro antimicrobial activity among seven bacteria. The presence of flavonoids indicates antimicrobial, antioxidant, anti-inflammatory as well as other medicinal properties in plants (Gutiérrez-Grijalva et al., 2017). Tannin is toxic to bacteria, fungi, and yeast and has some antibacterial and antiviral activity (Udegbunam et al., 2015). The existence of these phytochemical compounds in castor oil might be responsible for the antimicrobial activity in the oil. Further studies however on their properties are required to enhance its use by pharmaceutical industries as a value-added product for production of antibiotics in addition to its anti-inflammatory and purgative benefit.

\section{Carotenoids}

Carotenoids in oils act as an antioxidant to scavenge free radicals and may contribute to fat-soluble vitamins such as vitamin A activity. The combination of $\beta$-carotene and tocopherols in oils may synergistically provide antioxidant effect, while $\beta$-carotene alone can prevent lipid oxidation (Chew \& Nyam, 2019).

Carotenoids content found in castor oil ranged from 12.34-39.47 mg/kg $\beta$-carotene oil (Kadri et al., 2011). In another study, the carotenoids identified in castor oil was $2.05 \mathrm{mg} / \mathrm{kg}$ oil (Atta \& Mohamed, 2017). Comparing with other vegetable oils, the carotenoid content of castor oil is higher than soybean with $0.37 \mathrm{mg} / \mathrm{kg}$ oil and safflower at $1.21 \mathrm{mg} / \mathrm{kg}$ oil (Atta \& Mohamed, 2017). Mostly, at higher temperature carotenoid content easily degrade, and this might contribute to the low carotenoid in the oils.

In addition, carotenoids have been found to correlate with oils color which is one fundamental component to access oil quality (Chew \& Nyam, 2019). On determining the color of castor oil using Lovibond tintometer, it gave the red color 2.1 at 35 yellow (Atta \& Mohamed, 2017). The pale yellow color of castor oil signifies the presence of the yellow pigment, carotenoids. This pigment helps absorb ultraviolet radiations (Jemni et al., 2019).

\subsection{Physicochemical properties of castor oilseed}

Throughout literature, the density and refractive index of castor oilseed at $28^{\circ} \mathrm{C}$ are $961 \mathrm{~kg} / \mathrm{m}^{3}$ and 1.476 respectively (Omari et al., 2015; Torrentes-Espinoza et al., 2017). Castor oil has a viscosity of $1.86 \mathrm{St} / \mathrm{dPas}$ at $30^{\circ} \mathrm{C}$ (Yusuf et al., 2015) and 9.3-10 St/dPas at $25^{\circ} \mathrm{C}$ (Omari et al., 2015). The viscous nature of castor oil makes it appropriate for diesel fuel and coating (Naik et al., 2018). The castor oil quality can be determined by the acid, $p$-anisidine, iodine, saponification, and thiobarbituric acid.

\section{Iodine value}

The iodine value quantifies the unsaturation level of fats or oils and it is expressed in grams of iodine. A higher iodine value implies a higher level of unsaturation and lower value also indicates a low unsaturation level. In castor oilseed, the average range of iodine value is $83-93 \mathrm{~g} \mathrm{I}_{2} / 100 \mathrm{~g}$ oil (Omotehinse et al., 2019; Yusuf et al., 2015). This value indicates that the amount of iodine that will be present in the unsaturated acids is low. Castor oil can be regarded as a non-drying oil since the value is less than 100, hence making it useful for hydraulic brake fluids and lubricants. The iodine value sometimes differs among varieties. Zanzibar castor seeds ( $\mathrm{ZCOH}$ and $\mathrm{ZCOE}$ ) obtained from the same variety showed no significant difference in their iodine value when planted in the same area in Saudi Arabia (Sbihi et al., 2018). Variation did occur among Impala castor seeds obtained from the same variety (ICOH and ICOE) when they were cultivated in the same area which was attributed to their low PUFA content (Sbihi et al., 2018).

\section{Acid value}

The acid value determines the concentration of free fatty acids and is expressed as $\mathrm{mg} \mathrm{KOH} / \mathrm{g}$ oil. Acid value is one of the paramount indicators of oil quality. Vegetable oil with high acid content mostly has poor oil quality and during refining process, much oil is lost (Omari et al., 2015; Sbihi et al., 2018). Therefore, low acid value is a good indicator of vegetable oil and could be valuable for refining process. A number of reported acid values in castor oil ranges from 0.14 to $1.97 \mathrm{mg} / \mathrm{g}$ oil (Omari et al., 2015; Panhwar et al., 2016; Perdomo et al., 2013; Yusuf et al., 2015). Castor oilseeds planted in Nigeria had high acid values of 14.80 and $15.57 \mathrm{mg} / \mathrm{g}$ oil (Nangbes et al., 2013; Omohu \& Omale, 2017), but this could be associated to the poor handling and processing of the seed. According to American Society for testing and material (ASTM), the accepted acid value of vegetable oils should not exceed 2 (Yusuf et al., 2015). Omari et al., (2015) suggested that the high acid value of castor oil may be due to the delay in seed extraction which influenced the lipase enzyme to hydrolyze the triglycerides into free fatty acid. High acid value of $9.12 \mathrm{mg} / \mathrm{g}$ oil in chufa nuts was attributable to the splitting fat enzyme in the tuber that was found in low concentration which gradually hydrolyzed amygdalin (Aremu et al., 2016). 
Amygdalin is a glycoside that occurs naturally in plants to forms ester-linked bonds with fatty acids. Therefore, the occurrence of the enzyme might have gradually increase to hydrolytic oxidation as a result of the release of free fatty acids. In addition, the acid value of vegetable oils can be influenced by the type of solvent used in extraction. After analyzing the acid value in castor oil by using two different solvents, it was concluded that extraction by hexane gave good and quality oils compared to ethanol extraction (Sbihi et al., 2018).

\section{Anisidine value}

Anisidine value $(\mathrm{AnV})$ is a reliable and useful test that measures secondary oxidation products and reveals valuable information on compounds that are more stable and non-volatile during frying process (Schramm \& McGrath, 2013). It has been proposed that for oils to be classified as quality oil, its AnV should not be above two (Schramm \& McGrath, 2013). The AnV of castor oilseed was identified to be $1.66 \mathrm{meq} / \mathrm{kg}$ (Sedeek et al., 2012). This value is less compared to that reported in cottonseed oil and jojoba with 4.450 and $2.03 \mathrm{meq} / \mathrm{kg}$, respectively (Sedeek et al., 2012), suggesting that these oils are highly susceptible to oxidation than castor oil. Also, a negative AnV was observed (Yeboah et al., 2012). In AnV test, it is very rare for negative numbers to be obtained and, therefore this might be as a result of interference of water in reagents and samples from the artefact during the test process. A deep-frying study revealed that the AnV and stability of oil castor was better compared to the other oils under the study (Sedeek et al., 2012).

\section{Thiobarbituric acid}

Most often than not, anisidine and acid values are used to check the quality of vegetable oils. Thiobarbituric acid (TBA) is also another test that is widely used to access secondary oxidation products of oils. It measures the degree of malondialdehyde (MDA) and other related aldehyde compounds formed during the oxidation of oils (Sedeek et al., 2012). The TBA value of castor oil in deep frying was $0.58 \mathrm{mmol} / \mathrm{kg}$ which was lower than shea butter $4.39 \mathrm{mmol} / \mathrm{kg}$ and soybean oil $11.0 \mathrm{mmol} / \mathrm{kg}$ (Ikya et al., 2013; Sedeek et al., 2012). The low TBA value of castor signifies that the oil has longer keeping quality than shea butter and soybean oil assuming that TBA is an indicator of the extent in lipids. It was revealed that variation in peroxide, acid, iodine, and TBA values were well regulated and declined when castor/ jojoba oil mixtures was blended with cottonseed oil at ratios of 9:1 and 8:2 in a deep frying system (Sedeek et al., 2012). In the same frying study, castor and jojoba oil improved the stability of cottonseed oil which was attributable to the natural antioxidants and fatty acid composition in these oils (Sedeek et al., 2012).

\section{Saponification value}

One chemical property used to characterize castor oil is the saponification value which measures the molecular weight of the triglyceride. Low saponification value implies high molecular weight and high saponification value indicates low molecular weight of the triglyceride (Omari et al., 2015). The average range of saponification value reported in castor oilseed is 165.50 to $187 \mathrm{mg} \mathrm{KOH} / \mathrm{g}$ oil (Omari et al., 2015). The planting area has been found to be a major factor that influences the saponification value in oilseeds. Difference among saponification values grown in six different regions were found in castor. The highest value was recorded in Morogoro with $187.46 \mathrm{mg} \mathrm{KOH} / \mathrm{g}$ whereas Kagera had the lowest with $165.50 \mathrm{mg} \mathrm{KOH} / \mathrm{g}$ (Omari et al., 2015). Low saponification value in oil samples proposes their non-suitability for industrial use, hence the high saponification value of castor oil confirms its useful application for the manufacture of soaps and other cosmetic products.

\subsection{Composition and physicochemical properties of castor oilseed compared with other vegetable oils}

Castor oil has a bland taste and amber-color which is similar to that of virgin sunflower oil (Arshad \& Amjad, 2012; Ogunniyi, 2006). Comparative studies of the fatty acids composition of castor oilseed with some vegetable oils are presented in Table 3 . From the table, it can be observed that the range of saturated fatty acid (SFA) composition of castor oil is closely related to sunflower as indicated by their percentages and lower than palm kernel. Its high composition of monounsaturated fatty acid (MUFA) is similar to both olive oil and macadamia nut oil. Small amounts of PUFA in oils account for their high stability as reported in palm kernel oil, macadamia nut, and olive oil (Garg et al., 2007; Sinanoglou et al., 2014). Therefore, the low percentage of PUFA in castor oil may also contribute to its stability. Table 3 also indicates that the average total unsaturated fatty acid of castor is higher than barbados nut, palm kernel, pistachio, and macadamia nut, and falls within the range of rapeseed, olive, and sunflower (Sauder et al., 2014; Tavakolipour, 2015). From these observation, it can be said that the fatty acid profile of castor oil share similarities with macadamia nut, palm kernel, olive, and sunflower. However, its unsaturated fatty acid; ricinoleic acid is unique among all other vegetable oils, making it attractive for a wide spectrum of applications.

The composition of castor oilseed falls in line with oils that are nutritious and provides stability for a wide range of application. Such oils are mostly suitable for frying and industrial use because of their stability. Through gene slicing, Liu and colleagues developed cottonseed cultivar that gave high UFA and low SFA (Liu et al., 2002). It was believed that the oil gave higher stability compare to high oleic rapeseed or soybean oils. Based on the cultivar of castor oilseed and probably modification of the chemical structures, its oil can form part of oils that are commercially used for frying applications.

A number of studies have evaluated the oxidative stabilities of castor oil by using Rancimat test. This test measures the induction period from the point of oxidative rancidity in the oil (Said et al., 2016). The oxidation rate of castor oil starts gradually until it gets to the peak. The abrupt rise indicates the final induction period. The oxidative stabilities of castor oil with other oils have been studied. Rancimat test analysis at $100^{\circ} \mathrm{C}$ revealed that the induction period of castor, cottonseed, and jojoba oil were 135.2, 52.9, and $9.97 \mathrm{~h}$ respectively (Sedeek et al., 2012). Longer induction period implies higher stability, hence the longer period of castor oil signifies higher oxidative stability 
Table 3. Fatty acid profiles of castor oilseed with other oils.

\begin{tabular}{|c|c|c|c|c|c|c|}
\hline Oil & Botanical name & $\%$ SFA & $\%$ MUFA & $\%$ PUFA & $\begin{array}{c}\text { \% Total UFA } \\
\text { (MUFA+PUFA) }\end{array}$ & References \\
\hline Castor & $\begin{array}{l}\text { Ricinus } \\
\text { communis }\end{array}$ & $5.2-10.95$ & $78.29-83.35$ & $9.54-11.41$ & $87.83-94.76$ & $\begin{array}{l}\text { (Sbihi et al., 2018; } \\
\text { Yusuf et al., 2015) }\end{array}$ \\
\hline Barbados nut & Jatropha curcas & $21.6-26.3$ & $45.2-45.4$ & $32.2-33.0$ & $77.4-78.4$ & $\begin{array}{l}\text { (Akbar et al., 2009; Akintayo, } \\
\text { 2004; Rahman et al., 2014) }\end{array}$ \\
\hline Palm kernel & Elaeis guineensis & $52.1-85.01$ & $14.6-38.6$ & $2.4-11.6$ & $17.0-50.2$ & $\begin{array}{l}\text { (Asnaashari et al., 2015; Edem, } \\
\text { 2002; Nor Hayati et al., 2009) }\end{array}$ \\
\hline Sunflower & $\begin{array}{l}\text { Helianthus } \\
\text { annuus }\end{array}$ & 8.8-11.3 & $21.1-30.0$ & $59.0-70.0$ & $80.1-100$ & $\begin{array}{c}\text { (Chong et al., 2015; Edem, 2002; } \\
\text { Normand et al., 2001) }\end{array}$ \\
\hline Soyabean & Glycine max & $10.40-18.70$ & $17.70-26.10$ & $55.30-66.60$ & $73.0-92.7$ & $\begin{array}{c}\text { (Edem, 2002; Knothe, 2002; Nor } \\
\text { Hayati et al., 2009) }\end{array}$ \\
\hline Rapeseed & Brassica napus & $7.2-8.6$ & $58.5-68.0$ & $24.7-33.9$ & $83.2-101.9$ & $\begin{array}{c}\text { (Lewinska et al., 2015; } \\
\text { Szydłowska-Czerniak et al., 2010) }\end{array}$ \\
\hline Hazelnut & Corylus avellana & $6.30-16.7$ & $55.0-60.1$ & $14.8-33.4$ & $69.8-93.5$ & $\begin{array}{l}\text { (Ciemniewska- } \\
\text { Żytkiewicz et al., 2015; } \\
\text { Cristofori et al., 2008) }\end{array}$ \\
\hline Pistachio & Pistacia atlantica & $9.3-28.0$ & $8.56-49.57$ & $6.42-36.62$ & $14.98-86.19$ & $\begin{array}{l}\text { (Sauder et al., 2014; Tavakolipour, } \\
\text { 2015) }\end{array}$ \\
\hline Macadamia nut & $\begin{array}{c}\text { Macadamia } \\
\text { tetraphylla }\end{array}$ & $13.2-21.77$ & $75.69-82.4$ & $2.2-4.7$ & $77.89-87.1$ & $\begin{array}{c}\text { (Garg et al., 2007; } \\
\text { Sinanoglou et al., 2014) }\end{array}$ \\
\hline
\end{tabular}

compared to cottonseed and jojoba oil. In another study, the oxidative stability of castor oil was found to be higher than argan, nigella, olive, and sesame oils with an induction period of $35.5 \mathrm{~h}$ at $110^{\circ} \mathrm{C}$ (Said et al., 2016). Studies have confirmed that oxidative stability oils assessed by Rancimat test correlate with antioxidant systems (Abdallah et al., 2015; Sedeek et al., 2012). Therefore the stability of castor oil to oxidation could also be related to its high antioxidant properties such as tocopherols and probably the presence of ricinoleic acid which does not easily oxidize.

The range of unsaponifiable matter of cottonseed, coconut, and olive oils are $0.4-1.1,0.5$, and $0.7-1.4 \%$, respectively and these values are quite similar to castor oil which is $0.7 \%$ (Benitez-Sánchez et al., 2003; Ramos-Escudero et al., 2015; Yusuf et al., 2015). Extensive studies have been conducted on the unsaponifiable fraction of these oils in that alcoholic esters, hydrocarbons, triterpene alcohols, and waxes have been identified (Oderinde \& Tairu, 1992). Therefore, more studies are required in castor oil particularly on the various lipids, since these helps to identify the source of the lipids (Liu et al., 2002).

Phytosterols constitute major fraction of unsaponifiable matter in many oils. They are beneficial because of their antioxidant activity and positive influence on human health (Abdallah et al., 2015). The determination of the sterol profile and total sterol content is a reliable tool to evaluate authenticity of oils (Abdallah et al., 2015). The phytosterols components of the various vegetable oils have been shown in Table 4 . The overall phytosterol content $(1520.4-2603 \mathrm{mg} / 100 \mathrm{~g})$ in castor oilseed is similar to the range of olive oil (1800-2300 mg/100 g), and higher than walnuts (1085.60- $1573.63 \mathrm{mg} / 100 \mathrm{~g})$ and hazelnuts
(1458-1956 mg/100 g) (Said et al., 2016; Sbihi et al., 2018). The relative content of total phytosterol in cottonseed, rapeseed, sesame, and sunflower is higher than castor oilseed. The major phytosterol content found in castor oil is $\beta$-sitosterol with an average value of $1040.8-1181 \mathrm{mg} / 100 \mathrm{~g}$. This value is lower than all the reported $\beta$-sitosterol in this study. After $\beta$-sitosterol, the most predominant phytosterol in castor is stigmasterol followed by $\delta^{5}$-Avenasterol and campesterol. The percentage of these values are higher than the other oils except cottonseed, rapeseed, and sesame.

The contents of various isomers of tocopherol and tocotrienols in different vegetable oils are presented in Table 5 . The most dominant tocopherol component in castor oilseed is $\delta$ and $\gamma$ and the lowest is $\beta$ and $\alpha$. The mean value of $\delta$ and $\gamma$ are $43.1-96.62 \mathrm{mg} / \mathrm{g}$ and $30.89-52.7 \mathrm{mg} / \mathrm{g}$, respectively in castor oilseed making up a total of 73.99-149.32 mg/g (Said et al., 2016; Sbihi et al., 2018). These values are higher than those reported in olive, hazelnut, and sunflower as indicated in Table 5. High antioxidant and oxidative stability in oils such as cactus is associated to its higher $\delta$ and $\gamma$-tocopherol (Edem, 2002). In sunflower, the presence of tocopherol has been reported to protect the PUFA from oxidation (Fisk et al., 2006). According to Sattler et al. (2003), tocopherol is related with oil bodies to enhance the antioxidant protection for the seed. As such, the high amount of tocopherol in castor oil offer this same benefit. In addition to tocopherols, tocotrienols have several biological activities and could serve as antiosteoporotic agent (Edem, 2002). The major tocotrienols found in castor oilseed is $\beta$-tocotrienols, nevertheless, this value is extremely lower compared to palm kernel oil. Generally, it can be said that the vitamin E content in castor oilseed is lower than all the oils shown in Table 5. However, its values corresponds to 
Table 4. Phytosterols constituent in vegetable oil (mg/100 g).

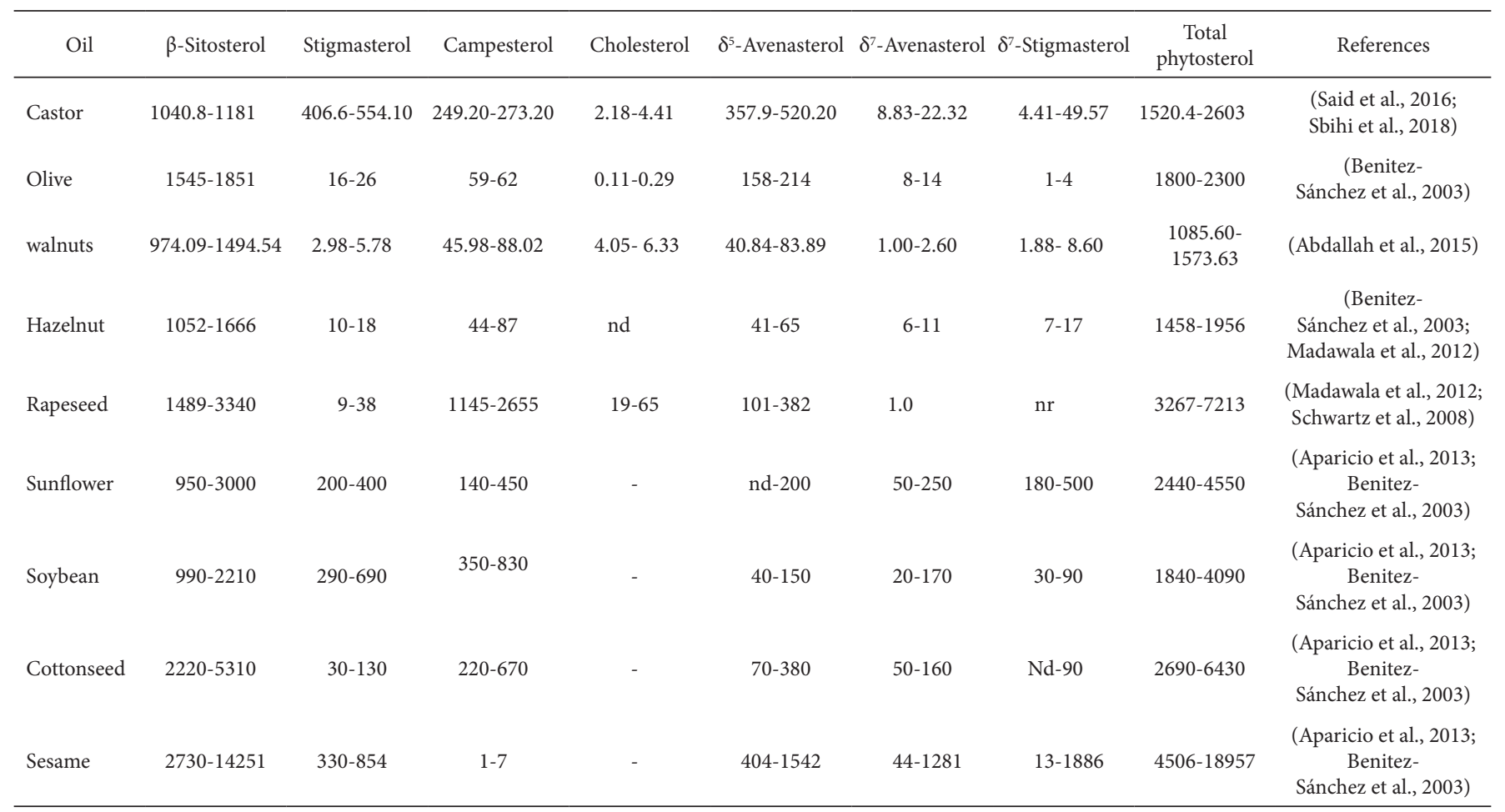

Keys; nr-not reported, nd-not detected.

Table 5. Vitamin E component of different oils.

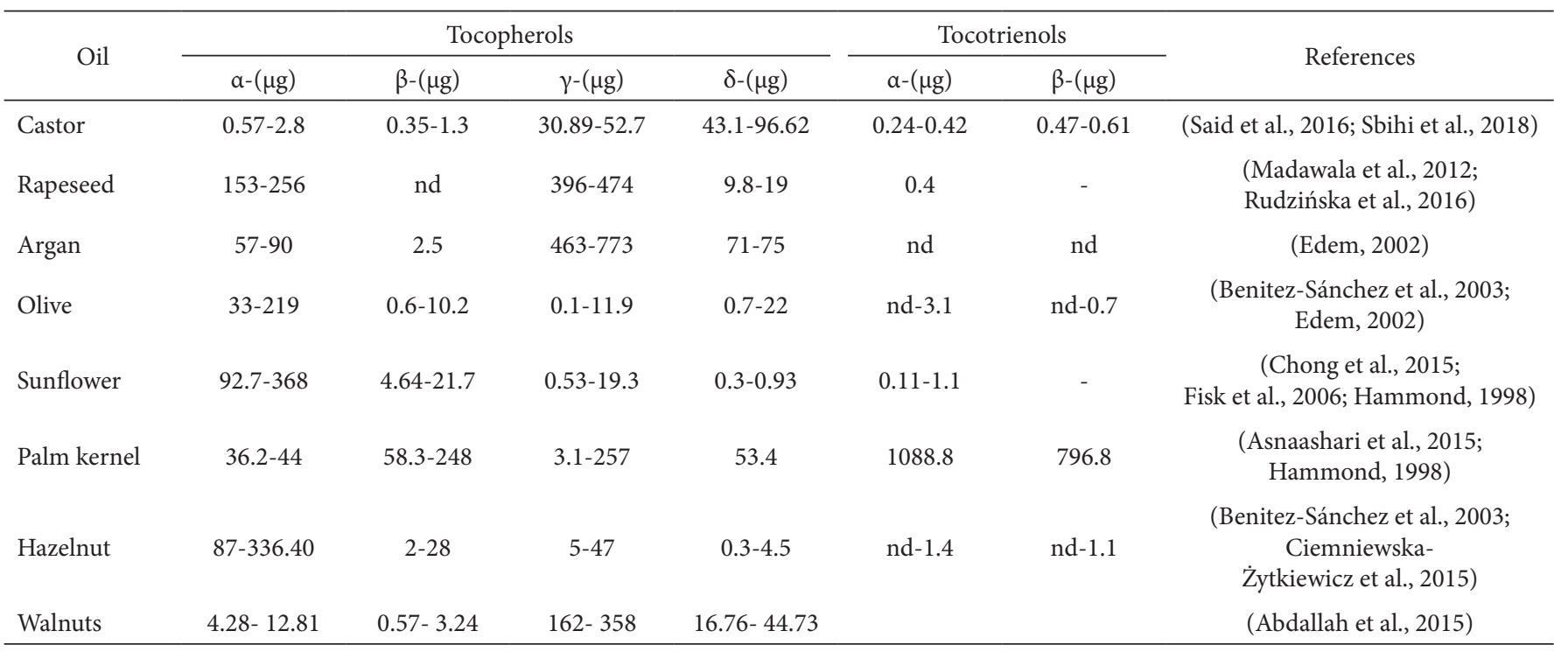

Keys; nd-not detected.

oils with high amount of Vitamin E rich in PUFA. The relatively proportion of tocopherols and tocotrienols in castor oilseed may contribute to the study of their relative in vivo and in vitro antioxidant effects.

The reported value of polyphenol content in castor oilseed was $632.33 \mu \mathrm{g} \mathrm{GAE} / \mathrm{g}$ and this amount was higher than phenolic content of Jatropha $408.00 \mu \mathrm{g}$ GAE/g (Rampadarath et al., 2014). Compared to other vegetable oils, it is relatively higher than the total amount of coconut ( $84 \mu \mathrm{g} \mathrm{GAE} / \mathrm{g})$, corn $(0.1 \mu \mathrm{g} \mathrm{GAE} / \mathrm{g})$, olive (26.5 $\mu \mathrm{g} \mathrm{GAE} / \mathrm{g})$, sunflower $(0.4 \mu \mathrm{g} \mathrm{GAE} / \mathrm{g})$, and soybean oil with 8 g GAE/g (Marfil et al., 2011; Nevin \& Rajamohan, 2006).

The phospholipid content (1-2\%) in castor oilseed falls within the range of that known in soybean (1.1-1.9\%) and sunflower oil with 1.2\% (Moreau et al., 1980; Subra-Paternault et al., 2015). The primary phospholipids mentioned in castor oilseed are similar to those in soybean and sunflower oil; phosphatidylcholines, 
phosphatidylethanolamines, and phosphatidylinositols (Benitez-Sánchez et al., 2003; Fisk et al., 2006).

In a deep frying study using castor, cottonseed, and jojoba, the viscosity of these oils increased gradually with time. Blending of castor and jojoba oil mixture at a ratio of 9:1 did not influence the viscosity of cottonseed oil. But an increase occurred after blending castor oil at a ratio of 8:2 (Sedeek et al., 2012). During frying, acceleration in viscosity is a normal phenomenon because of the formation of high molecular weight polymers. These polymers that are produced are more of oxygen which leads to the deterioration of oil, hence increasing the viscosity even more (Yaghmur et al., 2001). Though under actual industrial frying conditions, the polymers formed are low in oxygen and the oxygen content of oil is also low, the deterioration process becomes fast once the antioxidants produce are all used up. In this case, more viscous oils imply oils with a higher level of deterioration. In addition, changes in peroxide and acid values, as well as total polar compounds and TBA was observed when castor oil blended with cottonseed and jojoba oil in the deep frying system (Sedeek et al., 2012). During deep frying study, the acid value of argan, castor, cottonseed, and jojoba oil was found to be $0.4,1.848,1.026$ and 1.568 units, respectively (Sedeek et al., 2012; Yaghmur et al., 2001). Though the increase in argan oil is very small, it still falls within the range expected during deep frying. The sole use of peroxide value for testing oxidative deterioration of oils during frying is not recommended due to the reason being that peroxide easily gets decompose at high temperatures above $170^{\circ} \mathrm{C}$ and new peroxides are formed during cooling (Ikya et al., 2013).

One accepted method for assessing total oil alteration/ rancidity is by the determination of total polar compounds (TPC) (Ghobadi et al., 2018). This is because during frying processes polar compounds are formed from the decomposition of fatty acids. For cooking oils, the limit range for rejecting or replacing oils could be determined if the TPC is within 20 to $27 \%$ (Ghobadi et al., 2018). The acceptable range for fresh oils lies between 0.4 to $6.4 \%$. In the same frying study involving castor, the initial TPC of castor was 3.264 and this was lower than cottonseed 7.518 and jojoba oil 4.942 . After $12 \mathrm{~h}$ of frying, these values rose to $32.35,83.68$, and 32.35 for castor, cottonseed, and jojoba oil, respectively (Sedeek et al., 2012). This shows that during drying process, increasing time negatively affects the quality of oils, therefore the optimal range (time) should be known to avoid oil deterioration.

\section{Conclusion and prospects}

As it has been reviewed here, castor oilseed has high percentage of monounsaturated fatty acid and shares higher similarities of with other vegetable oils. The fatty acids profile and triglycerides demonstrate that ricinoleic acid and triricinolein are the predominant components in the oil. Bioactive compounds including polyphenols, phytosterols, and tocopherols present in castor oilseed pose its anti-inflammatory and antioxidant properties against oxidation and these may prolong the oil shelf life. The low acid value also accounts for castor oil stability.
Further studies, however on the composition and physicochemical properties are still required. The low percentage of total phospholipid content requires further study to enhance its utilization as emulsifier in different sectors. The limited studies on the unsaponifiable matter and its potential use for frying highlight the need for comprehensive research into this unique seed oil. Further studies on the different methods of extracting castor oil that is eco-friendly with maximal yields is required. Finally, breeding of cultivars that can be grown under challenging climatic conditions with higher yields and good oil quality should be taken into future consideration.

\section{Acknowledgements}

We are thankful to Ms. Adzigbli Linda, Asiamah Collins and all anonymous reviewers for making this manuscript a better one. We are thankful to the researchers whose contributions have been cited in this review paper, which have helped us to prepare a constructive review. Moreover, we apologize to those authors whose admirable work could not be cited due to space limitations. This study was funded by National Natural Science foundation of China (31271759); Guangdong provincial science and technology projects (2013b060400024, 2014a020208116, and 2016a020208015) (China); program for scientific research start-up funds of Guangdong Ocean University (Grant number, 521202290); project of enhancing school with innovation of Guangdong Ocean University, GDOU 2013050206 (China).

\section{References}

Abdallah, I. B., Tlili, N., Martinez-Force, E., Rubio, A. G. P., PerezCamino, M. C., Albouchi, A., \& Boukhchina, S. (2015). Content of carotenoids, tocopherols, sterols, triterpenic and aliphatic alcohols, and volatile compounds in six walnuts (Juglans regia L.) varieties. Food Chemistry, 173, 972-978. http://dx.doi.org/10.1016/j. foodchem.2014.10.095. PMid:25466114.

Akande, T. O., Odunsi, A., \& Akinfala, E. (2016). A review of nutritional and toxicological implications of castor bean (Ricinus communis L.) meal in animal feeding systems. Journal of Animal Physiology and Animal Nutrition, 100(2), 201-210. http://dx.doi.org/10.1111/ jpn.12360. PMid:26150062.

Akbar, E., Yaakob, Z., Kamarudin, S. K., Ismail, M., \& Salimon, J. (2009). Characteristic and composition of Jatropha curcas oil seed from Malaysia and its potential as biodiesel feedstock feedstock. European Journal of Scientific Research, 29(3), 396-403.

Akintayo, E. T. (2004). Characteristics and composition of Parkia biglobbossa and Jatropha curcas oils and cakes. Bioresource Technology, 92(3), 307-310. http://dx.doi.org/10.1016/S0960-8524(03)00197-4. PMid:14766165.

Alwaseem, H., Donahue, C. J., \& Marincean, S. (2014). Catalytic transfer hydrogenation of castor oil. Journal of Chemical Education, 91(4), 575-578. http://dx.doi.org/10.1021/ed300476u.

Anjani, K. (2012). Castor genetic resources: a primary gene pool for exploitation. Industrial Crops and Products, 35(1), 1-14. http://dx.doi. org/10.1016/j.indcrop.2011.06.011.

Anjani, K. (2014). A re-evaluation of castor (Ricinus communis L.) as a crop plant. Perspectives in Agriculture, Veterinary Science, Nutrition and Natural Resources, 9(1), 1-21. 
Aparicio, R., Conte, L. S., \& Fiebig, H.-J. (2013). Olive oil authentication Handbook of olive oil (pp. 589-653). Switzerland: Springer. http:// dx.doi.org/10.1007/978-1-4614-7777-8_16.

Aremu, M., Ibrahim, H., \& Aremu, S. (2016). Lipid Composition of Black Variety of Raw and Boiled Tigernut (Cyperus esculentus L.) Grown in North-East Nigeria. Pakistan Journal of Nutrition, 15(5), 427-438. http://dx.doi.org/10.3923/pjn.2016.427.438.

Arshad, M., \& Amjad, M. (2012). Medicinal use of sunflower oil and present status of sunflower in pakistan: A Review Study. Sci. Teacher Development, 31(2), 99-106.

Asnaashari, M., Hashemi, S. M., Mehr, H. M., \& Yousefabad, S. H. (2015). Kolkhoung (Pistacia khinjuk) hull oil and kernel oil as antioxidative vegetable oils with high oxidative stability and nutritional value. Food Technology and Biotechnology, 53(1), 81-86. http://dx.doi. org/10.17113/ftb.53.01.15.3719. PMid:27904335.

Atta, N. M., \& Mohamed, E. S. A. (2017). Determination of fat-soluble vitamins and natural antioxidants in seventeen vegetable oils. Journal of Food and Dairy Sciences, 8(8), 323-330. http://dx.doi. org/10.21608/jfds.2017.38892.

Baümler, E. R., Carrín, M. E., \& Carelli, A. A. (2017). Diffusion of tocopherols, phospholipids and sugars during oil extraction from sunflower collets using ethanol as solvent. Journal of Food Engineering, 194, 1-8. http://dx.doi.org/10.1016/j.jfoodeng.2016.09.003.

Benitez-Sánchez, P. L., León-Camacho, M., \& Aparicio, R. (2003). A comprehensive study of hazelnut oil composition with comparisons to other vegetable oils, particularly olive oil. European Food Research and Technology, 218(1), 13-19. http://dx.doi.org/10.1007/s00217003-0766-4.

Beruk, A. B., Abel, W. O., Assefa, A. T., \& Sintayehu, S. H. (2018). Studies on Ethiopian castor seed (Ricinus communis L.): extraction and characterization of seed oil. Journal of Natural Production Resource, 4(2), 188-190. http://dx.doi.org/10.30799/jnpr.064.18040204.

Beveridge, T. H. J., Girard, B., Kopp, T., \& Drover, J. C. G. (2005). Yield and composition of grape seed oils extracted by supercritical carbon dioxide and petroleum ether: varietal effects. Journal of Agricultural and Food Chemistry, 53(5), 1799-1804. http://dx.doi.org/10.1021/ jf040295q. PMid:15740076.

Borja, M. S., Oliveira, R. L., Silva, T. M., Bezerra, L. R., Nascimento, N. G., \& Borja, A. D. P. (2017). Effectiveness of calcium oxide and autoclaving for the detoxification of castor seed meal in finishing diets for lambs. Animal Feed Science and Technology, 231, 76-88. http://dx.doi.org/10.1016/j.anifeedsci.2017.07.001.

Boualem, M., Mokhtar, M., Saiah, F., Benourad, F., Bouhadiba, R., \& Berkani, A. (2017). Identification of Mentha piperita L. and Ricinus communis L. polyphenols by HPLC-DAD-ESI-MS and evaluation of their insecticidal properties against Aphis spiraecola P. South Asian Journal of Experimental Biology, 7(1), 28-34.

Brown, A. P., Kroon, J. T., Swarbreck, D., Febrer, M., Larson, T. R., Graham, I. A., Caccamo, M., \& Slabas, A. R. (2012). Tissue-specific whole transcriptome sequencing in castor, directed at understanding triacylglycerol lipid biosynthetic pathways. PLoS One, 7(2), e30100. http://dx.doi.org/10.1371/journal.pone.0030100. PMid:22319559.

Chakravartula, S. V., \& Guttarla, N. (2007). Identification and characterization of phenolic compounds in castor seed. Natural Product Research, 21(12), 1073-1077. http://dx.doi.org/10.1080/14786410701589766. PMid:17852742.

Chew, S. C., \& Nyam, K. L. (2019). Kenaf (Hibiscus cannabinus L.) seed oil. In M. F. Ramadan (Ed.), Fruit oils: chemistry and functionality (pp. 451-494). Switzerland: Springer.
Chong, Y. M., Chang, S. K., Sia, W. C. M., \& Yim, H. S. (2015). Antioxidant efficacy of mangosteen (Garcinia mangostana Linn.) peel extracts in sunflower oil during accelerated storage. Food Bioscience, 12, 18-25. http://dx.doi.org/10.1016/j.fbio.2015.07.002.

Ciemniewska-Żytkiewicz, H., Pasini, F., Verardo, V., Bryś, J., Koczoń, P., \& Caboni, M. F. (2015). Changes of the lipid fraction during fruit development in hazelnuts (Corylus avellana L.) grown in Poland. European Journal of Lipid Science and Technology, 117(5), 710-717. http://dx.doi.org/10.1002/ejlt.201400345.

Cristofori, V., Ferramondo, S., Bertazza, G., \& Bignami, C. (2008). Nut and kernel traits and chemical composition of hazelnut (Corylus avellana L.) cultivars. Journal of the Science of Food and Agriculture, 88(6), 1091-1098. http://dx.doi.org/10.1002/jsfa.3203.

Danlami, J. M., Zaini, M. A. A., Arsad, A., \& Yunus, M. A. C. (2015a). A parametric investigation of castor oil (Ricinus comminis L) extraction using supercritical carbon dioxide via response surface optimization. Journal of the Taiwan Institute of Chemical Engineers, 53, 32-39. http://dx.doi.org/10.1016/j. jtice.2015.02.033.

Danlami, J. M., Zaini, M. A. A., Arsad, A., \& Yunus, M. A. C. (2015b). Solubility assessment of castor (Ricinus communis L) oil in supercritical CO2 at different temperatures and pressures under dynamic conditions. Industrial Crops and Products, 76, 34-40. http:// dx.doi.org/10.1016/j.indcrop.2015.06.010.

Donaldson, R. P. (1976). Membrane lipid metabolism in germinating castor bean endosperm. Plant Physiology, 57(4), 510-515. http:// dx.doi.org/10.1104/pp.57.4.510. PMid:16659516.

Edem, D. O. (2002). Palm oil: biochemical, physiological, nutritional, hematological and toxicological aspects: A review. Plant Foods for Human Nutrition (Dordrecht, Netherlands), 57(3-4), 319-341. http:// dx.doi.org/10.1023/A:1021828132707. PMid:12602939.

Fisk, I. D., White, D. A., Carvalho, A., \& Gray, D. A. (2006). Tocopherolan intrinsic component of sunflower seed oil bodies. Journal of the American Oil Chemists' Society, 83(4), 341-344. http://dx.doi. org/10.1007/s11746-006-1210-2.

Gad-Elkareem, M. A., Abdelgadir, E. H., Badawy, O. M., \& Kadri, A. (2019). Potential antidiabetic effect of ethanolic and aqueousethanolic extracts of Ricinus communis leaves on streptozotocininduced diabetes in rats. PeerJ, 7, e6441. http://dx.doi.org/10.7717/ peerj.6441. PMid:30805250.

Ganesan, K., Sukalingam, K., \& Xu, B. (2018). Impact of consumption and cooking manners of vegetable oils on cardiovascular diseases-A critical review. Trends in Food Science \& Technology, 71, 132-154. http://dx.doi.org/10.1016/j.tifs.2017.11.003.

Garg, M. L., Blake, R. J., Wills, R. B. H., \& Clayton, E. H. (2007). Macadamia nut consumption modulates favourably risk factors for coronary artery disease in hypercholesterolemic subjects. Lipids, 42(6), 583-587. http://dx.doi.org/10.1007/s11745-007-3042-8. PMid:17437143.

Gharbi, I., Issaoui, M., Mehri, S., Cheraief, I., Sifi, S., \& Hammami, M. (2015). Agronomic and technological factors affecting Tunisian olive oil quality. Agricultural Sciences, 6(05), 513-526. http://dx.doi. org/10.4236/as.2015.65051.

Ghobadi, S., Akhlaghi, M., Shams, S., \& Mazloomi, S. M. (2018). Acid and peroxide values and total polar compounds of frying oils in fast food restaurants of Shiraz, Southern Iran. International Journal of Nursing Sciences, 3(1), 25-30.

Gunstone, F., \& Hamilton, R. (2004). The chemistry of oils and fats: sources. Composition, Properties and. 
Guo, S., Li, C., Zhang, Y., Yang, M., Jia, D., Zhang, X., Liu, G., Li, R., Bing, Z., \& Ji, H. (2018). Analysis of volume ratio of castor/soybean oil mixture on minimum quantity lubrication grinding performance and microstructure evaluation by fractal dimension. Industrial Crops and Products, 111, 494-505. http://dx.doi.org/10.1016/j. indcrop.2017.11.024.

Gutiérrez-Grijalva, E. P., Picos-Salas, M. A., Leyva-López, N., CriolloMendoza, M. S., Vazquez-Olivo, G., \& Heredia, J. B. (2017). Flavonoids and phenolic acids from oregano: occurrence, biological activity and health benefits. Plants, 7(1), 2. http://dx.doi.org/10.3390/ plants7010002. PMid:29278371.

Hammond, E. W. (1998). Analysis tocopherols and tocotrienols. Lipid Technology, 10(4), 86-88.

Huang, F., Bao, C., Peng, M., Zhu, G., He, Z., Chen, X., Luo, R., \& Zhao, Y. (2015). Chromatographic analysis of fatty acid composition in differently sized seeds of castor accessions. Biotechnology, Biotechnological Equipment, 29(5), 892-900. http://dx.doi.org/10.1 080/13102818.2015.1053410.

Ikya, J. K., Umenger, L. N., \& Iorbee, A. (2013). Effects of extraction methods on the yield and quality characteristics of oils from shea nut. Journal of Food Resource Science, 2(1), 1-12. http://dx.doi. org/10.3923/jfrs.2013.1.12.

Jemni, M., Chniti, S., \& Soliman, S. S. (2019). Date (Phoenix dactylifera L.) seed oil. In M. F. Ramadan (Ed.), Fruit oils: chemistry and functionality (pp. 815-829). Switzerland: Springer.

Kadri, A., Gharsallah, N., Damak, M., \& Gdoura, R. (2011). Chemical composition and in vitro antioxidant properties of essential oil of Ricinus communis L. Journal of Medicinal Plants Research, 5(8), 1466-1470.

Kelly, A. J., Kavanagh, J., \& Thomas, J. (2013). Castor oil, bath and/ or enema for cervical priming and induction of labour. Cochrane Database of Systematic Reviews, 7, CD003099. http://dx.doi. org/10.1002/14651858.CD003099.pub2. PMid:23881775.

Knothe, G. (2002). Structure indices in FA chemistry. How relevant is the iodine value? Journal of the American Oil Chemists' Society, 79(9), 847-854. http://dx.doi.org/10.1007/s11746-002-0569-4.

Lechner, M., Reiter, B., \& Lorbeer, E. (1999). Determination of tocopherols and sterols in vegetable oils by solid-phase extraction and subsequent capillary gas chromatographic analysis. Journal of Chromatography. A, 857(1-2), 231-238. http://dx.doi.org/10.1016/ S0021-9673(99)00751-7. PMid:10536841.

Lewinska, A., Zebrowski, J., Duda, M., Gorka, A., \& Wnuk, M. (2015). Fatty acid profile and biological activities of linseed and rapeseed oils. Molecules (Basel, Switzerland), 20(12), 22872-22880. http:// dx.doi.org/10.3390/molecules201219887. PMid:26703545.

Lin, J.-T. (2009). Ratios of regioisomers of triacylglycerols containing dihydroxy fatty acids in castor oil by mass spectrometry. Journal of the American Oil Chemists' Society, 86(11), 1031-1035. http://dx.doi. org/10.1007/s11746-009-1472-6.

Lin, J.-T., \& Chen, G. Q. (2012). Ratios of regioisomers of minor acylglycerols less polar than triricinolein in castor oil estimated by mass spectrometry. Journal of the American Oil Chemists' Society, 89(10), 1785-1792. http://dx.doi.org/10.1007/s11746-012-2083-1.

Liu, Q., Singh, S. P., \& Green, A. G. (2002). High-stearic and high-oleic cottonseed oils produced by hairpin RNA-mediated post-transcriptional gene silencing. Plant Physiology, 129(4), 1732-1743. http://dx.doi. org/10.1104/pp.001933. PMid:12177486.

Madawala, S. R. P., Kochhar, S. P., \& Dutta, P. C. (2012). Lipid components and oxidative status of selected specialty oils. Grasas y Aceites, 63(2), 143-151. http://dx.doi.org/10.3989/gya.083811.
Maleki, E., Aroua, M. K., \& Sulaiman, N. M. N. (2013). Improved yield of solvent free enzymatic methanolysis of palm and jatropha oils blended with castor oil. Applied Energy, 104, 905-909. http://dx.doi. org/10.1016/j.apenergy.2012.12.009.

Marfil, R., Giménez, R., Martínez, O., Bouzas, P. R., Rufián-Henares, J. A., Mesías, M., \& Cabrera-Vique, C. (2011). Determination of polyphenols, tocopherols, and antioxidant capacity in virgin argan oil (Argania spinosa, Skeels). European Journal of Lipid Science and Technology, 113(7), 886-893. http://dx.doi.org/10.1002/ejlt.201000503.

Möllers, C., \& Schierholt, A. (2002). Genetic variation of palmitate and oil content in a winter oilseed rape doubled haploid population segregating for oleate content. Crop Science, 42(2), 379-384. http:// dx.doi.org/10.2135/cropsci2002.3790.

Momoh, A. O., Oladunmoye, M., \& Adebolu, T. (2012). Evaluation of the antimicrobial and phytochemical properties of oil from castor seeds (Ricinus communis Linn). Bulletin of Environment. Pharmacology and Life Sciences, 1(10), 21-27.

Moreau, R. A., Liu, K. D., \& Huang, A. H. (1980). Spherosomes of castor bean endosperm: membrane components, formation, and degradation. Plant Physiology, 65(6), 1176-1180. http://dx.doi. org/10.1104/pp.65.6.1176. PMid:16661355.

Mubofu, E. B. (2016). Castor oil as a potential renewable resource for the production of functional materials. Sustainable Chemical Processes, 4(1), 11. http://dx.doi.org/10.1186/s40508-016-0055-8.

Mutlu, H., \& Meier, M. A. (2010). Castor oil as a renewable resource for the chemical industry. European Journal of Lipid Science and Technology, 112(1), 10-30. http://dx.doi.org/10.1002/ejlt.200900138.

Naik, B. (2018). Botanical descriptions of castor bean the castor bean genome (pp. 1-14). Switzerland: Springer.

Naik, S. N., Saxena, D. K., Dole, B. R., \& Khare, S. K. (2018). Potential and perspective of castor biorefinery waste biorefinery (pp. 623-656). USA: Elsevier.

Nangbes, J., Nvau, J., Buba, W., \& Zukdimma, A. (2013). Extraction and characterization of castor (Ricinus communis) seed oil. International Journal of Engineering Science, 2(9), 105-109.

Ndiaye, P. M., Tavares, F. W., Dalmolin, I., Dariva, C., Oliveira, D., \& Oliveira, J. V. (2005). Vapor pressure data of soybean oil, castor oil, and their fatty acid ethyl ester derivatives. Journal of Chemical \& Engineering Data, 50(2), 330-333. http://dx.doi.org/10.1021/je049898o.

Nevin, K., \& Rajamohan, T. (2006). Virgin coconut oil supplemented diet increases the antioxidant status in rats. Food Chemistry, 99(2), 260-266. http://dx.doi.org/10.1016/j.foodchem.2005.06.056.

Nezihe, A., Elif, D., Ozlem, Y., \& Tunçer, E. A. (2010). Microwave heating application to produce dehydrated castor oil. Industrial \& Engineering Chemistry Research, 50(1), 398-403. http://dx.doi.org/10.1021/ ie1013037.

Nor Hayati, I., Che Man, Y. B., Tan, C. P., \& Nor Aini, I. (2009). Physicochemical characteristics of soybean oil, palm kernel olein, and their binary blends. International Journal of Food Science \& Technology, 44(1), 152-161. http://dx.doi.org/10.1111/j.1365-2621.2007.01700.x.

Normand, L., Eskin, N., \& Przybyslki, R. (2001). Comparison of the stability of regular and high-oleic sunflower oils. Journal of the American Oil Chemists' Society, 84, 331-334.

Oderinde, R., \& Tairu, A. (1992). Determination of the triglyceride, phospholipid and unsaponifiable fractions of yellow nutsedge tuber oil. Food Chemistry, 45(4), 279-282. http://dx.doi.org/10.1016/03088146(92)90160-4.

Ogunniyi, D. S. (2006). Castor oil: a vital industrial raw material. Bioresource Technology, 97(9), 1086-1091. http://dx.doi.org/10.1016/j. biortech.2005.03.028. PMid:15919203. 
Omari, A., Mgani, Q. A., \& Mubofu, E. B. (2015). Fatty acid profile and physico-chemical parameters of castor oils in Tanzania. Green and Sustainable Chemistry, 5(4), 154-163. http://dx.doi.org/10.4236/ gsc.2015.54019.

Omohu, O. J., \& Omale, A. C. (2017). Physicochemical properties and fatty acid composition of castor bean Ricinus communis L. seed oil. European Journal of Biophysics, 5(4), 62-65. http://dx.doi. org/10.11648/j.ejb.20170504.11.

Omotehinse, S. A., Igboanugo, A. C., Ikhuoria, E. U., \& Ehigie, C. A. (2019). Characterization of castor seed oil extracted from the seed species native to Edo State, Nigeria. Journal of Science and Technology Research, 1(1), 45-54.

Panhwar, T., Mahesar, S. A., Mahesar, A. W., Kandhro, A. A., Talpur, F. N., Laghari, Z. H., Chang, A. S., \& Hussain Sherazi, S. T. (2016). Characteristics and composition of a high oil yielding castor variety from Pakistan. Journal of Oleo Science, 65(6), 471-476. http://dx.doi. org/10.5650/jos.ess15208. PMid:27250560.

Patel, V. R., Dumancas, G. G., Kasi Viswanath, L. C., Maples, R., \& Subong, B. J. (2016). Castor oil: properties, uses, and optimization of processing parameters in commercial production. Lipid Insights, 9, 1-12. http:// dx.doi.org/10.4137/LPI.S40233. PMid:27656091.

Perdomo, F. A., Acosta-Osorio, A. A., Herrera, G., Vasco-Leal, J. F., Mosquera-Artamonov, J. D., Millan-Malo, B., \& Rodriguez-Garcia, M. E. (2013). Physicochemical characterization of seven Mexican Ricinus communis L. seeds \& oil contents. Biomass and Bioenergy, 48, 17-24. http://dx.doi.org/10.1016/j.biombioe.2012.10.020.

Plante, M., Crafts, C., Bailey, B., \& Acworth, I. (2011). Characterization of castor oil by HPLC and charged aerosol detection (pp. 1-5). Canada: Dionex.

Rahman, M. M., Hassan, M. H., Kalam, M. A., Atabani, A. E., Memon, L. A., \& Rahman, S. A. (2014). Performance and emission analysis of Jatropha curcas and Moringa oleifera methyl ester fuel blends in a multi-cylinder diesel engine. Journal of Cleaner Production, 65, 304-310. http://dx.doi.org/10.1016/j.jclepro.2013.08.034.

Ramadan, M. F. (2019). Fruit oils: chemistry and functionality. Switzerland: Springer. http://dx.doi.org/10.1007/978-3-030-12473-1.

Ramanjaneyulu, A. V., Reddy, A. V., \& Madhavi, A. (2013). The impact of sowing date and irrigation regime on castor (Ricinus communis L.) seed yield, oil quality characteristics and fatty acid composition during post rainy season in South India. Industrial Crops and Products, 44, 25-31. http://dx.doi.org/10.1016/j.indcrop.2012.10.008.

Ramos-Escudero, F., Morales, M. T., \& Asuero, A. G. (2015). Characterization of bioactive compounds from monovarietal virgin olive oils: relationship between phenolic compounds-antioxidant capacities. International Journal of Food Properties, 18(2), 348-358. http://dx.doi.org/10.1080/10942912.2013.809542.

Rampadarath, S., Puchooa, D., \& Ranghoo-Sanmukhiya, V. M. (2014). A comparison of polyphenolic content, antioxidant activity and insecticidal properties of Jatropha species and wild Ricinus communis L. found in Mauritius. Asian Pacific Journal of Tropical Medicine, 7 (Suppl. 1), S384-S390. http://dx.doi.org/10.1016/S19957645(14)60263-7. PMid:25312155.

Razdi, W. A. W. (2012). Characterization and modification of castor oil extracted from the newly Malaysian produced castor beans. Pahang: University Malaysia Pahang.

Ribeiro, P. R., Fernandez, L. G., de Castro, R. D., Ligterink, W., \& Hilhorst, H. W. (2014). Physiological and biochemical responses of Ricinus communis seedlings to different temperatures: a metabolomics approach. BMC Plant Biology, 14(1), 223. http://dx.doi.org/10.1186/ s12870-014-0223-5. PMid:25109402.
Román-Figueroa, C., Olivares-Carrillo, P., Paneque, M., Palacios-Nereo, F. J., \& Quesada-Medina, J. (2016). High-yield production of biodiesel by non-catalytic supercritical methanol transesterification of crude castor oil (Ricinus communis). Energy, 107, 165-171. http://dx.doi. org/10.1016/j.energy.2016.03.136.

Rudzińska, M., Hassanein, M. M., Abdel-Razek, A. G., Ratusz, K., \& Siger, A. (2016). Blends of rapeseed oil with black cumin and rice bran oils for increasing the oxidative stability. Journal of Food Science and Technology, 53(2), 1055-1062. http://dx.doi.org/10.1007/ s13197-015-2140-5. PMid:27162385.

Saalmüller, L. (1848). Ueber die fetten Säuren des Ricinusöls. Justus Liebigs Annalen der Chemie, 64(1), 108-126. http://dx.doi.org/10.1002/ jlac.18480640105.

Said, G., Daniel, P., Badr, K., Mohamed, I., \& Zoubida, C. (2016). Chemical characterization and oxidative stability of castor oil grown in Morocco. Moroccan Journal of Chemistry, 4(2), 279-284.

Salihu, B., Gana, A., \& Apuyor, B. (2014). Castor oil plant (Ricinus communis L.): botany, ecology and uses. International Journal of Scientific Research (Ahmedabad, India), 3(5), 1334-1341.

Salimon, J., Noor, D. A. M., Nazrizawati, A., Yusoff, M. F. M., \& Noraishah, A. (2010). Fatty acid composition and physicochemical properties of Malaysian castor bean Ricinus communis L. seed oil. Sains Malaysiana, 39(5), 761-764.

Santos, P. M., Batista, D. L. J., Ribeiro, L. A. F., Boffo, E. F., de Cerqueira, M. D., Martins, D., de Castro, R. D., de Souza-Neta, L. C., Pinto, E., Zambotti-Villela, L., Colepicolo, P., Fernandez, L. G., Canuto, G. A. B., \& Ribeiro, P. R. (2018). Identification of antioxidant and antimicrobial compounds from the oilseed crop Ricinus communis using a multiplatform metabolite profiling approach. Industrial Crops and Products, 124, 834-844. http://dx.doi.org/10.1016/j. indcrop.2018.08.061.

Sattler, S. E., Cahoon, E. B., Coughlan, S. J., \& DellaPenna, D. (2003). Characterization of tocopherol cyclases from higher plants and cyanobacteria. Evolutionary implications for tocopherol synthesis and function. Plant Physiology, 132(4), 2184-2195. http://dx.doi. org/10.1104/pp.103.024257. PMid:12913173.

Sauder, K. A., McCrea, C. E., Ulbrecht, J. S., Kris-Etherton, P. M., \& West, S. G. (2014). Pistachio nut consumption modifies systemic hemodynamics, increases heart rate variability, and reduces ambulatory blood pressure in well-controlled type 2 diabetes: a randomized trial. Journal of the American Heart Association, 3(4), e000873. http://dx.doi.org/10.1161/JAHA.114.000873. PMid:24980134.

Sbihi, H. M., Nehdi, I. A., Mokbli, S., Romdhani-Younes, M., \& AlResayes, S. I. (2018). Hexane and ethanol extracted seed oils and leaf essential compositions from two castor plant (Ricinus communis L.) varieties. Industrial Crops and Products, 122, 174-181. http:// dx.doi.org/10.1016/j.indcrop.2018.05.072.

Schramm, J. H., \& McGrath, J. W., Jr., inventors; PBM Pharmaceuticals, Inc., assignee. (2013). Oral compositions comprising edible oils and vitamins and/or minerals and methods for making oral compositions. US8075910B2.

Schwartz, H., Ollilainen, V., Piironen, V., \& Lampi, A.-M. (2008). Tocopherol, tocotrienol and plant sterol contents of vegetable oils and industrial fats. Journal of Food Composition and Analysis, 21(2), 152-161. http://dx.doi.org/10.1016/j.jfca.2007.07.012.

Sedeek, S., El-Ghobashy, R., \& Tawfik, M. (2012). Thermal stability of cottonseed oil mixed with jojoba or castor oil during frying process. Journal of Biological Chemistry and Environmental Science, 7(2), 39-56. 
Severino, L. S., Auld, D. L., Baldanzi, M., Cândido, M. J., Chen, G., Crosby, W., Tan, D., He, X., Lakshmamma, P., Lavanya, C., Machado, O. L. T., Mielke, T., Milani, M., Miller, T. D., Morris, J. B., Morse, S. A., Navas, A. A., Soares, D. J., Sofiatti, V., Wang, M. L., Zanotto, M. D., \& Zieler, H. (2012). A review on the challenges for increased production of castor. Agronomy Journal, 104(4), 853-880. http:// dx.doi.org/10.2134/agronj2011.0210.

Severino, L. S., Mendes, B. S., \& Lima, G. S. (2015). Seed coat specific weight and endosperm composition define the oil content of castor seed. Industrial Crops and Products, 75, 14-19. http://dx.doi. org/10.1016/j.indcrop.2015.06.043.

Sinadinović-Fišer, S., Janković, M., \& Borota, O. (2012). Epoxidation of castor oil with peracetic acid formed in situ in the presence of an ion exchange resin. Chemical Engineering and Processing: Process Intensification, 62, 106-113. http://dx.doi.org/10.1016/j.cep.2012.08.005.

Sinanoglou, V. J., Kokkotou, K., Fotakis, C., Strati, I., Proestos, C., \& Zoumpoulakis, P. (2014). Monitoring the quality of $\gamma$-irradiated macadamia nuts based on lipid profile analysis and Chemometrics. Traceability models of irradiated samples. Food Research International, 60, 38-47. http://dx.doi.org/10.1016/j.foodres.2014.01.015.

Souza Schneider, R. C., Baldissarelli, V. Z., Trombetta, F., Martinelli, M., \& Caramão, E. B. (2004). Optimization of gas chromatographicmass spectrometric analysis for fatty acids in hydrogenated castor oil obtained by catalytic transfer hydrogenation. Analytica Chimica Acta, 505(2), 223-226. http://dx.doi.org/10.1016/j.aca.2003.10.070.

Subra-Paternault, P., ThongDeng, H., Grélard, A., \& Cansell, M. (2015). Extraction of phospholipids from scallop by-product using supercritical CO2/alcohol mixtures. Lebensmittel-Wissenschaft + Technologie, 60(2), 990-998. http://dx.doi.org/10.1016/j.lwt.2014.09.057.

Szydłowska-Czerniak, A., Trokowski, K., Karlovits, G., \& Szłyk, E. (2010). Determination of antioxidant capacity, phenolic acids, and fatty acid composition of rapeseed varieties. Journal of Agricultural and Food Chemistry, 58(13), 7502-7509. http://dx.doi.org/10.1021/ jf100852x. PMid:20545342.

Tavakolipour, H. (2015). Postharvest operations of pistachio nuts. Journal of Food Science and Technology, 52(2), 1124-1130. http:// dx.doi.org/10.1007/s13197-013-1096-6. PMid:25694728.

Torrentes-Espinoza, G., Miranda, B., Vega-Baudrit, J., \& Mata-Segreda, J. F. (2017). Castor oil (Ricinus communis) supercritical methanolysis. Energy, 140, 426-435. http://dx.doi.org/10.1016/j.energy.2017.08.122.
Udegbunam, I., Vie, A., \& Wunuji, H. (2015). Evaluataion of the phytochemical and antimicrobial properties of ethyl acetate leaf extract of palicourea croceiodes. European Journal of Biotechnology and Bioscience, 3(3), 19-23.

Velasco, L., Fernández-Cuesta, Á., Pascual-Villalobos, M. J., \& FernándezMartínez, J. M. (2015). Variability of seed quality traits in wild and semi-wild accessions of castor collected in Spain. Industrial Crops and Products, 65, 203-209. http://dx.doi.org/10.1016/j.indcrop.2014.12.019.

Velasco, L., Rojas-Barros, P., \& Fernández-Martínez, J. M. (2005). Fatty acid and tocopherol accumulation in the seeds of a high oleic acid castor mutant. Industrial Crops and Products, 22(3), 201-206. http:// dx.doi.org/10.1016/j.indcrop.2004.11.002.

Wilson, R., Van Schie, B., \& Howes, D. (1998). Overview of the preparation, use and biological studies on polyglycerol polyricinoleate (PGPR). Food and Chemical Toxicology, 36(9-10), 711-718. http://dx.doi. org/10.1016/S0278-6915(98)00057-X. PMid:9737417.

Yaghmur, A., Aserin, A., Mizrahi, Y., Nerd, A., \& Garti, N. (2001). Evaluation of argan oil for deep-fat frying. Lebensmittel-Wissenschaft + Technologie, 34(3), 124-130. http://dx.doi.org/10.1006/fstl.2000.0697.

Yeboah, S. O., Mitei, Y. C., Ngila, J. C., Wessjohann, L., \& Schmidt, J. (2012). Compositional and structural studies of the oils from two edible seeds: Tiger nut, Cyperus esculentum, and asiato, Pachira insignis, from Ghana. Food Research International, 47(2), 259-266. http://dx.doi.org/10.1016/j.foodres.2011.06.036.

Yin, X., Lu, J., Agyenim-Boateng, K. G., \& Liu, S. (2019). Breeding for Climate resilience in castor: current status, challenges, and opportunities genomic designing of climate-smart oilseed crops (pp. 441-498). Switzerland: Springer.

Ying, S., Hill, A. T., Pyc, M., Anderson, E. M., Snedden, W. A., Mullen, R. T., She, Y. M., \& Plaxton, W. C. (2017). Regulatory phosphorylation of bacterial-type PEP carboxylase by the Ca2+-dependent protein kinase RcCDPK1 in developing castor oil seeds. Plant Physiology, 174(2), 1012-1027. http://dx.doi.org/10.1104/pp.17.00288. PMid:28363991.

Yusuf, A., Mamza, P., Ahmed, A., \& Agunwa, U. (2015). Extraction and characterization of castor seed oil from wild Ricinus communis Linn. International Journal of Science, Environment and Technology, 4(5), 1392-1404. 